\title{
Nunduva, a new marine genus of Rivulariaceae (Nostocales, Cyanobacteria) from marine rocky shores
}

\author{
Laura GonZÁLeZ-Resendiz*1, Jeffrey R. Johansen ${ }^{2,3}$, Luisa Alba-Lois ${ }^{4}$, Claudia \\ SEGAL-KISCHINEVZKY ${ }^{4}$, Viviana EsCOBAR-SÁNCHEZ ${ }^{4}$, Luis F. JiMENEZ GARCIA ${ }^{4}$, Tomáš \\ HAUER $^{3,5} \&$ Hilda LEÓN-TEJERA ${ }^{1}$
}

\author{
${ }^{1}$ Departamento de Biología Comparada, Facultad de Ciencias, Universidad Nacional Autónoma de México \\ (UNAM). Coyoacán, Código Postal 04510, Ciudad de México México; *Corresponding author e-mail: \\ mlauragonzalez@ciencias.unam.mx \\ ${ }^{2}$ Department of Biology, John Carroll University, University Heights, Ohio, 44118 USA \\ ${ }^{3}$ Department of Botany, Faculty of Science, University of South Bohemia, Branišovská 1760, 37005 České \\ Budějovice, Czech Republic \\ ${ }^{4}$ Departamento de Biología Celular, Facultad de Ciencias, UNAM, Ciudad de México, México \\ ${ }^{5}$ Centre for Phycology, Institute of Botany AS CR, Dukelská 135, 37982 Třebon̆, Czech Republic
}

\begin{abstract}
Several populations of a non-tapering and tapering, fasciculated, single and geminate false branching heterocytous cyanobacterium were collected from rocky shores in the Pacific Ocean and Gulf of Mexico. The populations were provisionally placed in Brasilonema based on morphology, but upon sequencing of both environmental and culture material it was discovered that the populations/cultures belonged to the Rivulariaceae, in a marine subclade of the family containing Kyrtuthrix huatulcensis. In culture, the taxon exhibited tapering in isopolar filaments, providing further evidence that it was a member of the rivulariacean clade. Based on molecular data for other cyanobacteria within the rivulariacean clade, we identified at least three more species morphologically distinguishable from the Brasilonema-like material, all of which show more pronounced tapering. These cyanobacteria include not only tropical marine strains, but also a strain isolated from the English coastline in the Atlantic Ocean. We propose a new genus and four species for members of this distinctive clade, Nunduva fasciculata gen. nov., sp. nov., N. kania sp. nov., N. biania sp. nov., and N. britannica sp. nov. Other strains that others and we have isolated are sister to Nunduva and may eventually be placed within this genus, but at present, we consider the evidence for inclusion in Nunduva to be insufficient.
\end{abstract}

Key words: 16S rRNA gene, 16S-23S ITS region, Calothrix, geminate branching, intertidal, isopolar growth, marine, Nostocales, Rivulariaceae, Gulf of México, Pacific, Atlantic, European

\section{INTRODUCTION}

Despite the large number of papers that have been published in recent years, the taxonomic diversity of cyanobacteria in tropical environments is still poorly known (NABout et al. 2013; HAUER et al. 2013). Several special morphotypes representing new species and genera of cyanobacteria have recently been described in tropical and extreme habitats (KOMÁREK \& KoMÁrKová 2007; Gamma et al. 2014; Gold-Morgan et al. 2015; Alvarenga et al. 2016; HentsChKe et al. 2016; MisCOE et al. 2016). The polyphasic approach, which combines morphological and molecular methods, allows greater precision and recognition of taxonomic diversity, as well as a means of revision of the hierarchical classification of some cyanobacterial taxa to better reflect their evolutionary history (FioRE et al. 2007; HAUER et al. 2014; Genuario et al. 2015). Phylogenetic analyses based on molecular markers, especially the 16S rRNA gene, have been the basis for the reorganization of some traditional cyanobacterial families (GEITLER 1932; HAUER et al. 2014; KOMÁREK et al. 2014).

Based on molecular phylogenetic analyses, numerous morphologically well-defined genera have been found to be polyphyletic e.g., Anabaena, Nostoc, Tolypothrix, and Calothrix among others (RAJANIEMI et al. 2005; HAUER et al. 2014; KOMÁreK et al. 2014; GeNUARIO et al. 2015; BERRENDERo et al. 2016). This problem can only be corrected through a careful taxonomic revision that can result in the description of new genera, or the 
unification of different generic entities.

The family Rivulariaceae is comprised presently of 10 genera (Rivularia, Calothrix, Dichothrix, Gardnerula, Isactis, Sacconema, Microchaete, Phyllonema, Macrochaete and Kyrtuthrix - see KomáreK et al. 2014; Alvarenga et al. 2016; BERRENDERO et al. 2016; LEÓN-TEJERA et al. 2016). The family includes mainly heteropolar forms with tapered trichomes, which are widest at the base and sometimes end in a hyaline hair with thin, elongated cells, possess an obligately basal heterocyte in mature trichomes, and reproduce by hormogonia (BERRENDERO et al. 2016). Recently Kyrtuthrix was placed in the Rivulariaceae, even though it has isopolar trichomes and no basal heterocytes. However, it does possess an attenuated, heteropolar, differentiated growth form (LEÓN-TEJERA et al. 2016). The Scytonemataceae and Symphyonemataceae are similar to Kyrtuthrix in that they have tapering isopolar trichomes, but they are widest in the middle of the trichome and are phylogenetically distant (KoMÁREK 2013). These findings show that the traditional morphological concept of the Rivulariaceae has been expanded, but still does not include all tapering heterocytous genera.

During studies of marine cyanobacteria from supra and intertidal fringes of tropical regions of the Mexican coast, we have found that most of the benthic rocky shore mats are dominated by heterocytous cyanobacterial morphotypes (GoNZÁLEZ-RESENDIZ et al. 2015). Frequently, a special morphotype was found, resembling Brasilonema in the Scytonemataceae in filament morphology, intercalary heterocytes, fasciculated filaments and scarce geminate or single branching. However, our populations differ from Brasilonema in ecology and morphology in various characters such as the shape of the apical cell, as well as the development in culture of isopolar and heteropolar hormogonia and markedly tapering trichomes and formation of a long hair not seen in natural material. In addition to the Brasilonema-like populations, mucilaginous populations with isopolar tapering trichomes similar to Scytonematopsis were also found, isolated, and sequenced as part of our ongoing interest in the cyanobacteria of tropical rocky shores. Through phylogenetic analysis, we found a number of other marine tapering taxa sequenced by others, which apparently shared a close relationship with our tapering and nontapering taxa.

The aim of this study was to characterize these populations, employing a polyphasic approach, incorporating morphological, ecological and molecular information.

\section{Materials ANd Methods}

Samples were collected in supratidal and intertidal fringes from San Agustín Bay (1541'17.41"N, 96¹4'15.28"W), Tangolunda bay $\left(15^{\circ} 46^{\prime} 24.79^{\prime \prime} \mathrm{N}, 96^{\circ} 5^{\prime} 28.32^{\prime \prime} \mathrm{W}\right)$ and Playa Hermosa Beach $\left(18^{\circ} 40^{\prime} 03.8^{\prime \prime} \mathrm{N}, 95^{\circ} 07^{\prime} 47.7^{\prime \prime} \mathrm{W}\right)$ in the Mexican coasts.

Twelve samples were analyzed, eight from San Agustín Bay, three from Tangolunda Bay, and one from Playa Hermosa
Beach. Each sample was divided into three parts: one dried subsample for culturing, one part fixed in formalin, and one part dried in silica gel.

Morphological characterization was performed on formalin-preserved samples of different populations. Semi-permanent slides were prepared and micrographs were acquired with an Olympus DP12 digital camera adapted to an Olympus BX51 microscope. Morphological measurements $(n=30)$ were obtained from micrographs using SigmaScan Pro $\subset$ automated image analysis software (Jandel Scientific, Sausalito, California). A separate strain, long in culture, was obtained from the CCAP culture collection (Microchaete grisea CCAP 1445/1), characterized in the light microscope, and sequenced as part of another study (HAUER et al. 2014). This phylogenetically close strain was added to this study when we realized it belonged to the same clade as our other strains.

Transmission electron microscopy (TEM) images of field material were obtained in a JEOL mod JEM 1010 microscope after fixation in 6\% glutaraldehyde in $0.1 \mathrm{M}$ PBS and subsequent post-fixation in $1 \%$ osmium tetroxide, dehydration in ethanol series and embedding in epoxy resin. Ultrathin sections were contrasted with uranyl acetate and lead citrate according to REYNOLDS (1963).

Morphological identification was done in accordance with recent and traditional reference works (GEITLER 1932; FRÉMY 1934; KOMÁREK 2013), and several papers that report tropical and subtropical rocky shore taxa (SANT'ANNA et al. 1985; Sant'AnNa 1988; Sant'AnNa 1997; LeÓN-TeJera et al. 2005). Systematic assignment was made according to the system of KomÁreK et al. (2014).

Material isolation and strains. Dry samples were rehydrated with sterile seawater on a microscopy slide and filaments were isolated through serial dilutions in drops of seawater. Reduction or elimination of sheath was obtained by washing for one hour with Extran ${ }^{\circledR} 1 \%$, (in order to get rid of epiphytes), then afterwards rinsed four or five times with liquid SN medium (WATERBURY et al. 1986), followed by an additional two or three rinses with semi-solid SN medium (to eliminate sheath and epiphyte remnants). The seawater was filtered with 0.45 and $0.22 \mu \mathrm{m}$ Millipore ${ }^{\circledR}$ membranes and sterilized. Strains C58-M5-K83, C458-M16-K66, C694-M8-K148, and C708-M10-K85, were isolated from enrichment media cultures in Petri plates with solid agar SN, the plates were incubated at $25^{\circ} \mathrm{C}$ in a $12 / 12 \mathrm{~h}$, light/dark regime in a culture chamber. Additional strains of marine Rivulariaceae were isolated following the same protocols (C1088-M21-K118, C1230-M22-K135, C708-M3-KA), and additional is environmental materials characterized and sequenced (but not isolated) include C57-M6, C57-M7, C923-M12, C1290-M9).

Molecular methods and phylogenetic analyses. DNA was extracted from cultures and environmental samples, using the UltraClean ${ }^{\circledR}$ Microbial DNA Isolation kit (MoBio Laboratories, Carlsbad, CA) according to manufacturer's instructions. The 16S rRNA gene and 16S-23S ITS region, were amplified using primers 27F after NEILAN et al. (1997), and VRF1 after WiLmotTe et al. (1993). The PCR amplification was performed with an Eppendorf Mastercycler following the conditions described by LEÓN-TEJERA et al. (2016). PCR products were gel purified, quantified, and cloned with the CloneJET PCR Cloning Kit (ThermoFisher Scientific, Waltham, MA). One or two clones with verified long PCR products were then chosen for each strain for sequencing at the Biotechnology Institute, UNAM sequencing facility using an Applied Biosystems (Foster 
City, CA) model 3130xl Genetic Analyzer. We assembled and corrected sequences obtained using Bioedit software version 7.0.9.0 (Hall 1999). The GenBank accession numbers for consensus sequences (for those samples with multiple sequences) of Nunduva and closely related taxa are HE797730, KT936560-72, and AM230677-78.

A total of 260 sequences were chosen for the phylogenetic analysis, including the four consensus sequences obtained in this study as well as representatives of the main groups of heterocytous cyanobacteria available in GenBank, and three outgroup taxa (Chroococcidiopsis 9E-07 FR798923, Chroococcidiopsis cubana SAG39.79 AJ344558 and Chroococcidiopsis thermalis AB039005). All sequences were aligned using default parameters in CLUSTAL W Multiple Sequence Alignment Program (Thompson et al. 1994) and manually edited in PhyDE $\AA$ version 0.9971 (MÜLLER et al. 2010).

Phylogenetic relationships were inferred with maximum parsimony analysis (MP) and maximum likelihood analysis (PhyML) in Seaview v4 (Gouy et al. 2010; GuIndon et al. 2010). Bootstrapping with 1000 replicates was conducted for both analyses. Bayesian analysis (BA) was run in MrBayes 3.2.2 (Ronquist et al. 2012), using two independent runs with eight chains each, for ten million generations with default parameters and first $25 \%$ of sampled trees were discarded as burn-in. The evolutionary model GTR $+\mathrm{I}+\Gamma$ was determined based on the Maximum Likelihood (ML) ratio test implemented by TOPALi version 2 software (MILNE et al. 2009). The BA had a mean estimated sample size (ESS) exceeding 2000 for all parameters (ranging 2,655-7369), well above the average of 200 typically accepted as sufficient by phylogeneticists (DrumMOND et al. 2006). The final average standard deviation of split frequencies was $<0.038$. The potential scale reduction factor (PSRF) value for all the estimated parameters in the Bayesian analysis was 1.00 , indicating that convergence of the MCMC chains was statistically achieved (GELMAN \& RUBIN 1992). The range of 16S rRNA gene divergence values within and among species was calculated using uncorrected p-distance in Mega V6.

Secondary structure of ITS region. The secondary structures of the 16S-23S ITS region were determined using a combination of comparative analysis of the secondary structures of our strains, with additional related taxa from the 16S rRNA phylogeny. In addition to Nunduva species, we selected representatives of close related clades Kyrtuthrix huatulcensis and "Rivularia" PCC 7116 (phylogenetically not in Rivularia sensu stricto). The construction of secondary structures of D1-D1', Box-B, V2 and V3 helices were determined separately using Mfold version 2.3 (ZUKER 2003), and illustrated and corrected in Adobe Illustrator.

\section{RESULTS}

We obtained ten consensus sequences of the 16S rRNA gene with their associated 16S-23S ITS region (2037 to $2090 \mathrm{bp}$ ) for cultured strains and environmental isolates of a new genus within the Rivulariaceae. Morphological characterization of this taxon was previously reported in GoNZÁLEZ-RESENDIZ et al. (2015), but is named and formally described here.
Nunduva GonzÁLEz-RESENDIZ, LEÓN-TEJERA et JoHANSEN gen. nov. (Figs 1A-110)

Diagnosis: Differing from all other genera in the Rivulariaceae in that trichomes possess geminate and single false branching. Phylogenetically distant from all Scytonemataceae and Calothrix spp. from freshwater, soil, and thermal habitats (Fig. 10).

Description: Colonies caespitose on rocks in the marine habitat, formed by filaments arranged in erect fascicles, with heteropolar appearance achieved after basal fragmentation. Sheaths lamellate, thin or wide, becoming diffluent at the end, colorless or yellow-brown, and roundly closed or open at the end. Trichomes are untapered or distinctly tapered at some phase of life-cycle and/or in culture material, sometimes developing a hyaline or semi-hyaline hair, vacuolated or not; with geminate and single false branches, mainly in basal parts of filaments. Trichomes constricted or not at cross walls, in both environmental samples and strains. Cells of variable length and shape, shorter than wide to almost isodiametric in environmental and culture material. Heterocytes are basal or intercalary, solitary or serial $(-3)$, of variable length and shape. Hormogonia, isopolar or heteropolar, produced through trichome fragmentation, with or without necridic cells, cell constriction or heterocyte breakup. Akinetes unobserved.

Etymology: Nunduva (Mixtec) = Oaxaca. Mixtec is the language spoken by one of the ethnic groups of Oaxaca, a State located in Southwestern Mexico where some these populations are found.

Type species: Nunduva fasciculata GonZÁLEZ-RESENDIZ, LEÓN-TEJERA et JOHANSEN sp. nov.

Nunduva fasciculata GoNZÁLEZ-RESENDIZ, LEÓN-TEJERA et JoHANSEN sp. nov. (Figs 1A-5I)

Description: Thallus caespitose, composed of blackishgreen erect filaments densely fasciculate (Figs 1A-1B, $3 \mathrm{~A}), 2-3 \mathrm{~cm}$ high, filaments with rare geminate false branching, 9-15 $\mu \mathrm{m}$ wide (Fig. 1C). Sheaths firm, cylindrical, stratified, yellowish brown (Figs 1C, 1G-1H, 2B, 4A) Trichomes cylindrical, constricted or not at cross-walls, 6-10 $\mu \mathrm{m}$ wide (Figs $1 \mathrm{H}, 1 \mathrm{~J}, 1 \mathrm{~K}$ ); slightly tapered towards the ends as well as in hormogonia (Figs $2 \mathrm{~K}, 4 \mathrm{~A}$ ); apical cell colorless, distinctively short and spherical-rounded, bead-like (Figs 1D-1G, 5D-5E). Cells with blue-green to olive-green granulated content (Fig. $1 \mathrm{~K}$ ), isodiametric in old filaments, 5 to $8 \mu \mathrm{m}$ long, shorter than wide in apical zones, 2-3 $\mu \mathrm{m}$ long 5.6-7 wide. Heterocytes intercalary, elongated, flattened, discoid or cylindrical 8-15 $\mu \mathrm{m}$ long, up to 2 to 3 times longer than wide, 4.5-6.7 $\mu \mathrm{m}$ long, 1.8-4.8 $\mu \mathrm{m}$ wide, rarely three short heterocytes contiguous or near one another (Figs $1 \mathrm{H}-\mathrm{J}$, 2A-2B). Reproduction by isopolar hormogonia attached to filaments, straight or more frequently crescent-shaped (Figs 2G-2J, 3B, 3D-3F, 4C, 5C, 5G, 5I). Hormogonia, produced by necridic cell or heterocytes formation (Figs 
2B-2G, 5H) Akinetes not observed in environmental or culture conditions. Transmission electron microscopy (TEM) images obtained from Nunduva fasciculata field material show thylakoids disposed in packets (Fig. 4B) with isopolar hormogonia with bead-like terminal cell (Fig. 4C).

Habitat: Supratidal and intertidal fringe; epilithic on granitic rock.

Type locality: MEXICO. Oaxaca: San Agustín Bay, $15^{\circ} 41^{\prime} 17.41^{\prime \prime} \mathrm{N}, 96^{\circ} 14^{\prime} 15.28^{\prime \prime} \mathrm{W}$, October 2012. C694 collected by L. González-Resendiz \& H. León-Tejera. Holotype here designated: Dry material FCME-C694 from environmental sample deposited at Herbarium of Faculty of Sciences, Universidad Nacional Autónoma de México, (UNAM), Ciudad de México. Figures 1D-1F; $1 \mathrm{H}-1 \mathrm{~K} ; 2 \mathrm{~B} ; 2 \mathrm{~F}-2 \mathrm{I} ; 2 \mathrm{~K}-5 \mathrm{I}$.

Isotypes: FCME-C57, FCME-C58 (environmental samples) and dry material of FCME strain C694-M8K148. Herbarium of Faculty of Sciences, Universidad Nacional Autónoma de México, UNAM. México.

Paratypes: FCME-C36, -C645, -C719,-C737, -C1313, -C1288,-C1289 and -C1290 (environmental samples). Herbarium of Faculty of Sciences, Universidad Nacional Autónoma de México, UNAM. México.

Reference strain: FCME C694-M8-K148.

Etymology: fasciculata (Latin), referring to the fasciculate growth form.

Notes: Some of the important features in populations from environmental material changed in culture, while other traits remained constant. The characteristic smaller rounded apical cell was lost in culture and replaced by a tapering trichome with a long pigmented hair. Environmental material rarely had geminate false branching, but false branching increased markedly in culture material. In young colonies (30 days after the inoculation) populations show mixed characteristics concerning the differentiation of terminal cell and tapering of the trichomes. In old cultures ( 24 months), the fasciculate growth form did not change and heteropolar hormogonia are more abundant than the isopolar ones (Figs $3 \mathrm{~A}-3 \mathrm{H}$ ).

\section{Nunduva kania JoHANSEN, González-RESENDIZ et} LEón-TEJERA sp. nov. (Figs 6A-6J)

Description: Thallus filamentous, heteropolar and isopolar $(6 \mathrm{~B}, 6 \mathrm{D}, 6 \mathrm{~F}-6 \mathrm{H})$, with frequent geminate false branching $(6 \mathrm{~A}, 6 \mathrm{D}, 6 \mathrm{~F})$. Sheaths diffluent, lamellate, colorless, open at the end. Trichomes constricted at cross walls, 1.7-2.6 $\mu \mathrm{m}$ long, 7.5-9 $\mu \mathrm{m}$ wide, tapered to form long hair composed by semi-hyaline and "vacuolated" cells up to $1-1.5 \mu \mathrm{m}$ wide $(6 \mathrm{~A}, 6 \mathrm{E}-6 \mathrm{~F})$. Cells with olive-green granulated content, 2 to $5 \mu \mathrm{m}$ long, wider than long; in the apical zone cells are longer than wide, $1.7-2.8 \mu \mathrm{m}$ long, $1.2-1.5 \mu \mathrm{m}$ wide. Heterocytes basal and no more than one, conical or hemispherical in shape (4.9-5.4 $\mu \mathrm{m}$ wide $2.5-2.6 \mu \mathrm{m}$ long) $(6 \mathrm{~F}-6 \mathrm{H})$. Reproduction by heteropolar and isopolar hormogonia, produced by separation of branches and by deep cell constriction without necridic cell (Figs 6B-6D, 6E, 6H-6J arrows). Akinetes not observed in culture conditions.

Habitat: Intertidal fringe; epilithic on basaltic rock. Type locality: MEXICO. Veracruz: Playa Hermosa, $18^{\circ} 40^{\prime} 03.8^{\prime \prime N}, 95^{\circ} 07^{\prime} 47.7^{\prime \prime} \mathrm{W}$, April 2012. C458 Collected by H. León-Tejera \& L. González-Resendiz.

Holotype here designated: Dry material of FCME strain C458-M16-K66 deposited at Herbarium of Faculty of Sciences, Universidad Nacional Autónoma de México, (UNAM), Ciudad de México. Figures 6A-6J.

Reference strain: FCME C458-M16-K66.

Etymology: kani (Mixtec) = "Large", due to long hair.

Notes: The description is based on material cultivated in SN medium. The long hair and basal heterocyte are the main morphological traits that differentiate this species from $N$. fasciculata, $N$. biania and $N$. britannica. The heteropolar trichome developed by hormogonia is released by constriction of cells from the mature filament; the isopolar trichomes develop from branch separation. Apical ends may differentiate, one becomes slightly wider and produces a single terminal heterocyte, and the other extreme cells become elongated, tapering, forming a long hair or sometimes hormogonia.

\section{Nunduva biania LEón-TeJERA, GoNZÁLEZ-RESENDIZ et JoHANSEN sp. nov. (7A-80)}

Description: Thallus caespitose, composed of yellowish-brown erect heteropolar filaments, $3-8 \mu \mathrm{m}$ wide (Fig. 7A), with rare single false branching. Sheaths diffluent, lamellate, colorless to yellowish, and flared at the apex (Figs 7B-7D, 8B, 8L-8O arrows). Trichomes cylindrical, constricted or not at cross-walls, 2-7 $\mu \mathrm{m}$ wide, slightly swollen at base and tapered without hair (Figs 7A, 7D-7E, 7H, 8A, 8-8F, 8L-8O). Cells shorter than wide, with olive-green granulated content, 1-2.7 $\mu \mathrm{m}$ long in basal zone; $0.5-0.8 \mu \mathrm{m}$ long in apical zone. Heterocytes intercalary or basal, elongated, discoid or cylindrical, 4-4.5 $\mu \mathrm{m}$, long 4-6 $\mu \mathrm{m}$ wide, rarely two short heterocytes contiguous or near one another (Figs 7B-7C, 7F-7G, 8D arrow). Reproduction by isopolar hormogonia that may remain temporarily within the sheaths (Fig. 7H), or heteropolar hormogonia produced by cell constriction, or heterocyte formation and by separation of branches (Figs 8F, 8L, 8J, $8 \mathrm{O}$ arrows). Akinetes not observed in environmental or culture conditions.

Habitat: Intertidal fringe; epilithic on granitic rock Type locality: MEXICO. Oaxaca: San Agustín Bay, $15^{\circ} 41^{\prime} 17.41^{\prime \prime} \mathrm{N}, 96^{\circ} 14^{\prime} 15.28^{\prime \prime} \mathrm{W}$, October 2012. C708 Collected by L. González-Resendiz \& H. León-Tejera. Holotype here designated: Dry material of FCME strain C708-M-10-K85 deposited at Herbarium of Faculty of Sciences, Universidad Nacional Autónoma de México, (UNAM), Ciudad de México. Figures: 8A-80.

Isotype: FCME-C708 (environmental sample). 

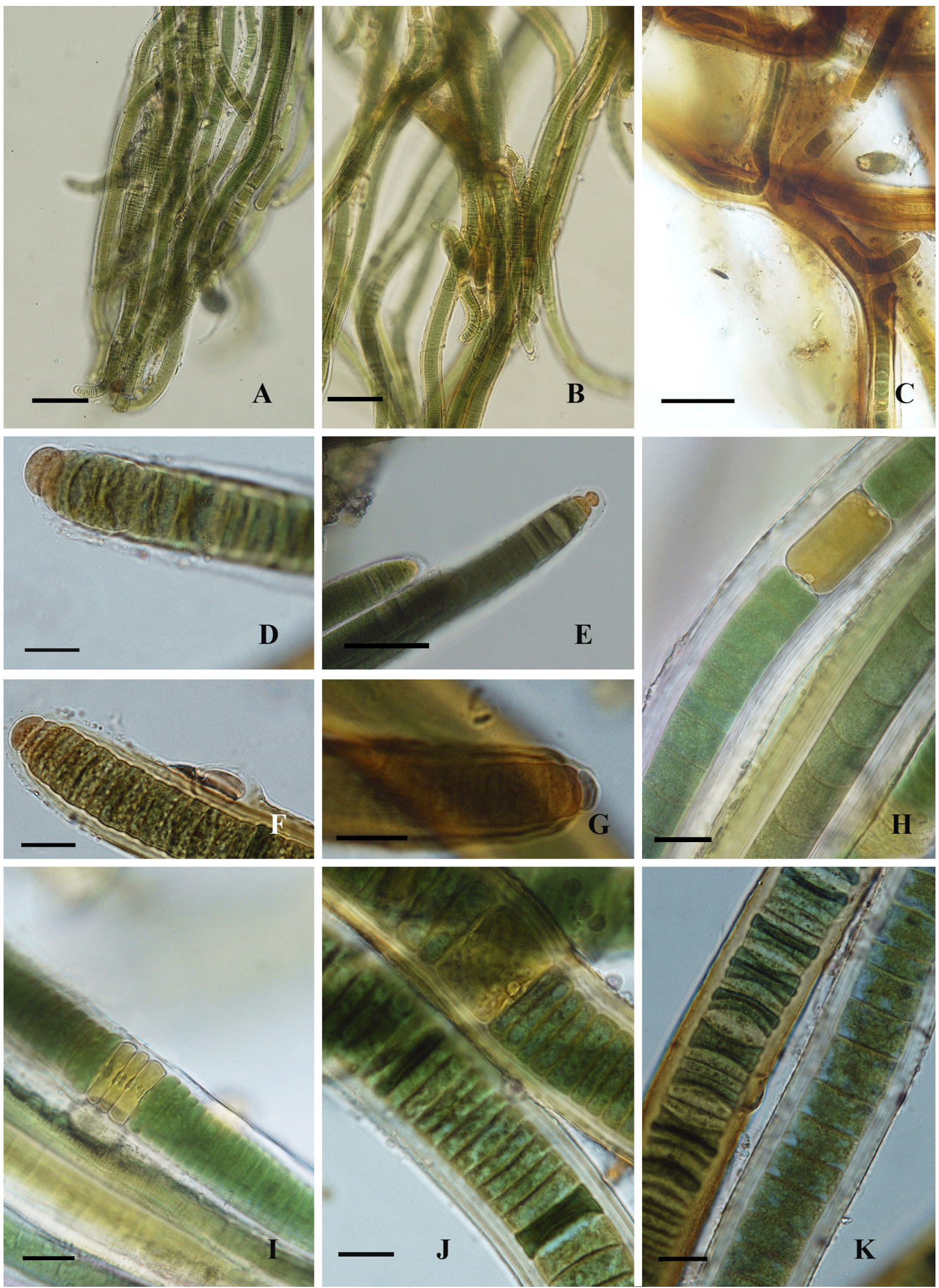

Fig. 1. Nunduva fasciculata environmental populations: (A-B) filaments disposed in fascicles; (C) geminate branching; (D-G) bead-like apical cell development in slightly attenuated trichomes; $(\mathrm{H}-\mathrm{J})$ variable dimensions and disposition of heterocytes: single or in series; (J-K) variable cell dimensions. Scale bars $30 \mu \mathrm{m}(\mathrm{A}-\mathrm{B}), 20 \mu \mathrm{m}(\mathrm{C}), 10 \mu \mathrm{m}(\mathrm{D}-\mathrm{K})$. 

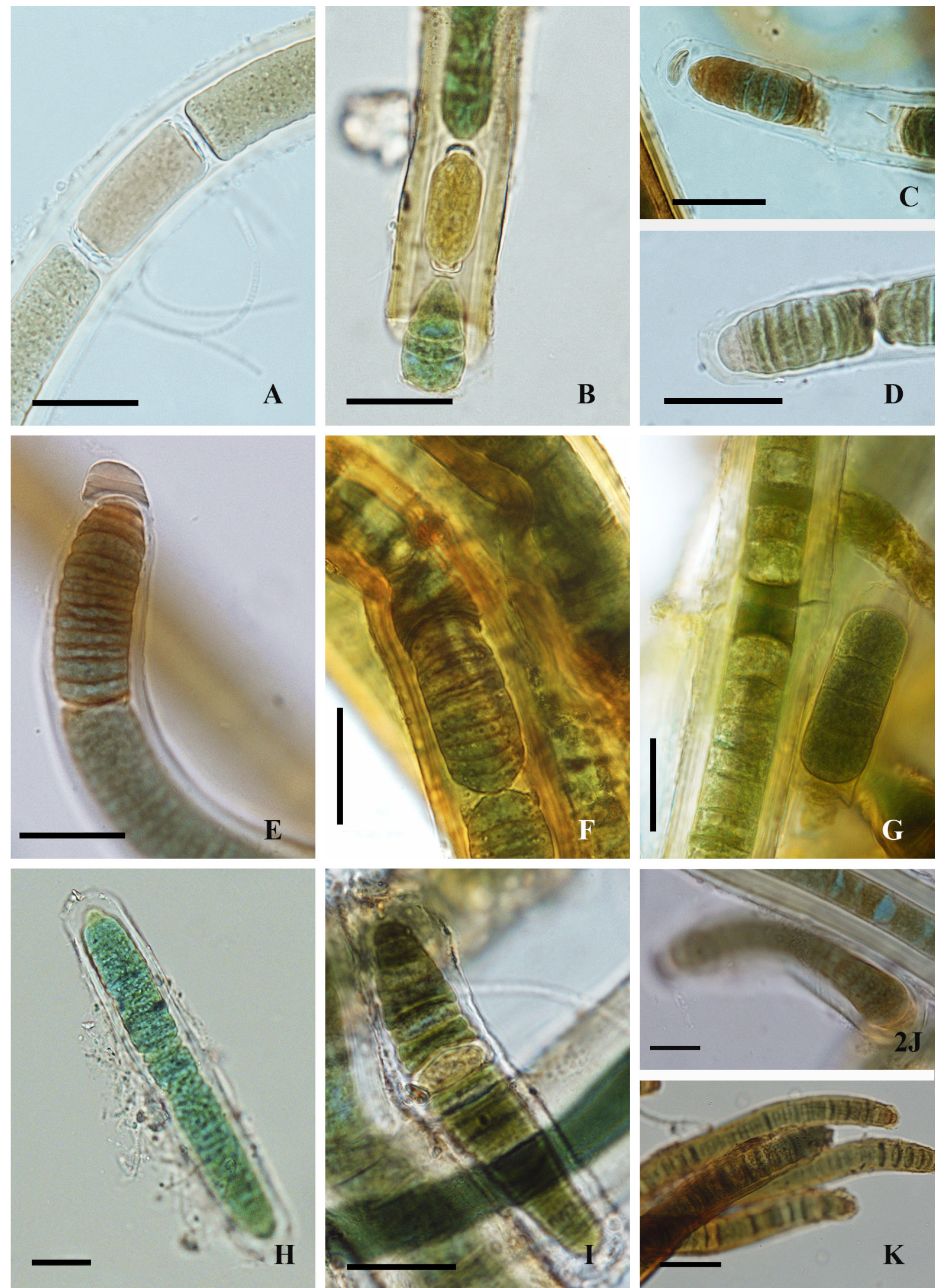

Fig. 2. Nunduva fasciculata environmental populations: (A-B) wide sheath, hyaline or pigmented; (C-E) stages of terminal hormogonia development; (F) non-terminal hormogonia development; $(\mathrm{G}-\mathrm{I})$ different stages of isopolar hormogonial development, some with slightly attenuated terminal part; $(\mathrm{J})$ heteropolar curved hormogonia; $(\mathrm{K})$ filaments arranged in fascicles. Scale bars $10 \mu \mathrm{m}(\mathrm{A}-\mathrm{J}), 20 \mu \mathrm{m}(\mathrm{K})$. 


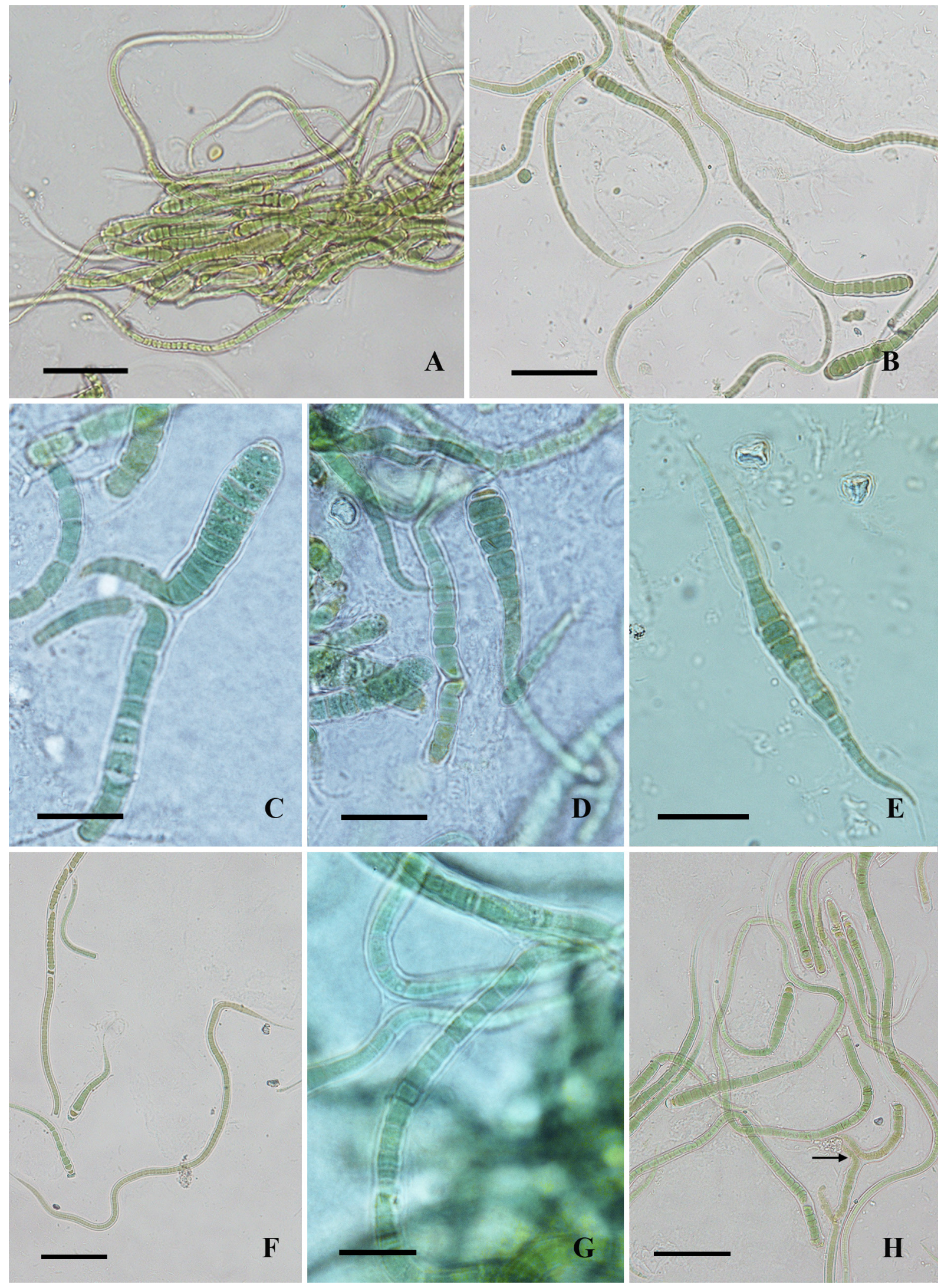

Fig. 3. Nunduva fasciculata culture populations: (A) filaments arranged in fascicles; (B, D) heteropolar development of hormogonia into non-mature filaments; $(C)$ geminate branching of hormogonia; $(E)$ isopolar development of hormogonia; $(\mathrm{F})$ isopolar mature filaments; $(\mathrm{G}-\mathrm{H})$ mature filaments with geminate branches. Scale bars $30 \mu \mathrm{m}(\mathrm{A}, \mathrm{B}, \mathrm{F}, \mathrm{H}), 10 \mu \mathrm{m}(\mathrm{C}-\mathrm{E}, \mathrm{G})$. 

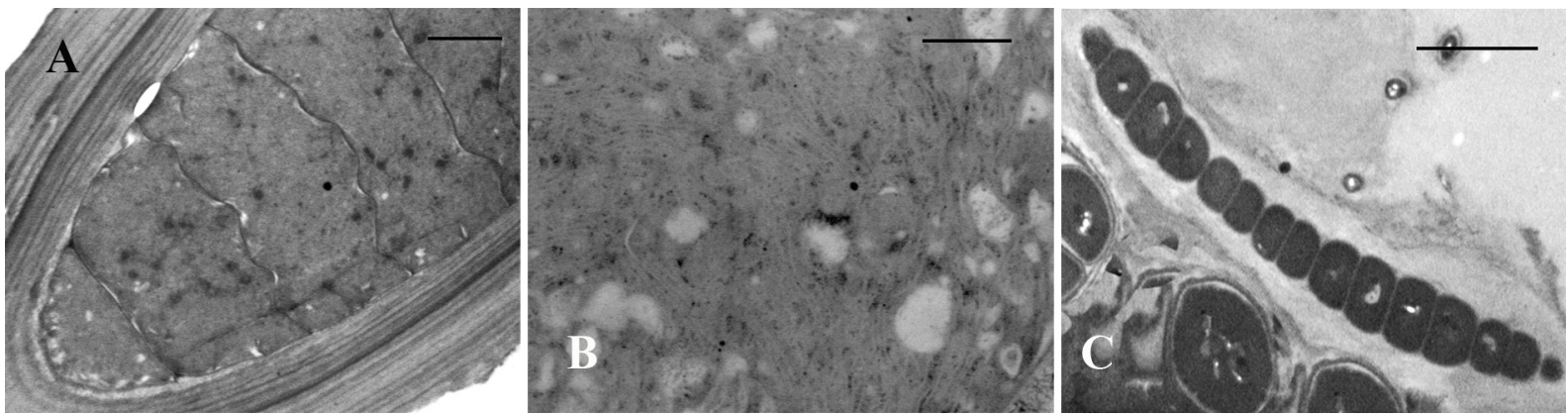

Fig. 4. Nunduva fasciculata, TEM micrographs of environmental populations: (A) stratified sheath of terminally attenuated filament; (B) thylakoids arranged in irregular packets; (C) isopolar hormogonia with thickened sheath. Scale bars $3 \mu \mathrm{m}$ (A), $1 \mu \mathrm{m}$ (B), $4 \mu \mathrm{m}$ (C).

A

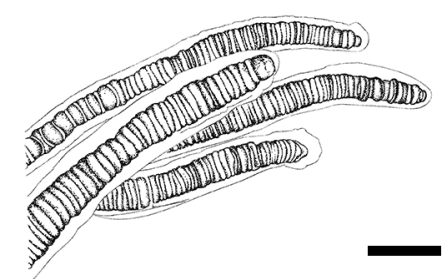

D

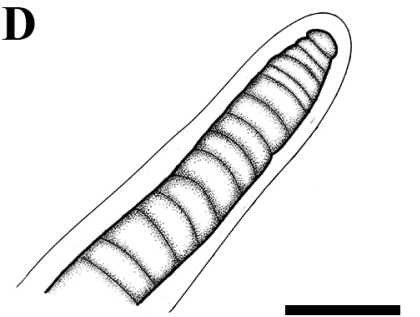

G

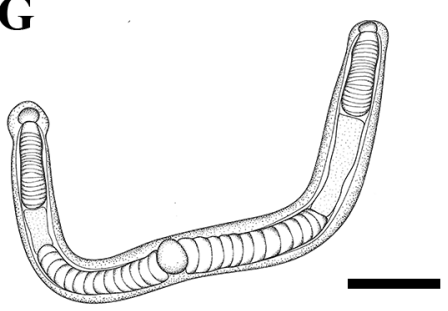

B

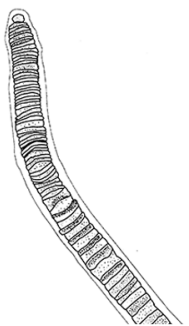

$\mathbf{E}$

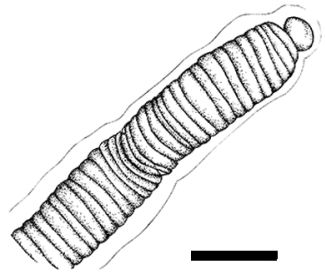

$\mathbf{H}$

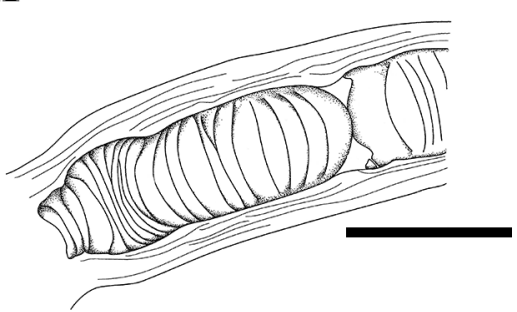

C

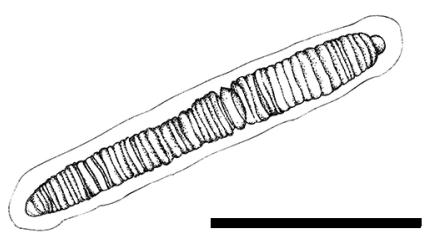

$\mathbf{F}$

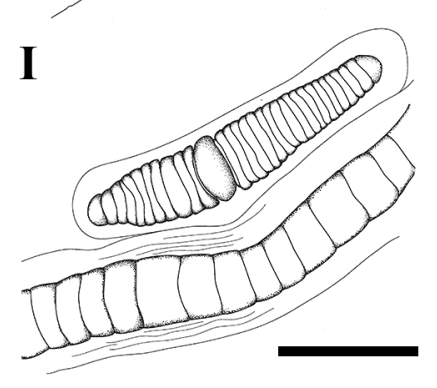

Fig. 5. Nunduva fasciculata, drawings of environmental populations: (A) filaments arranged in fascicles; (B-E) bead-like apical cell development in slightly attenuated trichomes; $(F)$ trichome with variable cell dimensions; $(\mathrm{G})$ isopolar curved hormogonia with enlarged heterocytes; (H) non-terminal hormogonial development; (I) isopolar hormogonia adherant to mature filament. Scale bars $20 \mu \mathrm{m}(\mathrm{A}, \mathrm{B}, \mathrm{G}), 10 \mu \mathrm{m}(\mathrm{C}-\mathrm{F}$, $\mathrm{H}-\mathrm{I})$.

Reference strain: FCME C708-M10-K85.

Etymology: biani (Zapotec) = "lamp" referring to the apical form of sheath in culture that seems as oil lamp

Notes: The heteropolar growth form does not change in culture and environmental conditions. In culture, sheath is straight to undulate, thin to sometimes prominent, stratified, becoming diffluent and opens to form a flared "oil lamp" shape at the apex. Environmental material does not have geminate false branching, but in culture simple or geminate branches are common. In culture cells are wider than long, with diameter more or less homogeneous, variously constricted, becoming attenuated and longer towards terminal parts. Intercalary or basal heterocytes are few and small in SN media with supplied nitrogen. Cytoplasm with small to big granules. Hormogonia isopolar, developing mainly intercalarly (Figs 8H-8I, 8O), those heteropolar upon release are terminal, strongly tapered, and proximal to the widened lamp-shaped end of the sheath (Figs 8B, 8M-8O).

Nunduva britannica Hauer sp. nov. (Figs 9A-K)

Description: Young cultures with heteropolar filaments, straight or wavy, taper towards the end, 5-11 um wide, 
with thin, colorless unstratified sheath, with geminate false branching (Fig. 9A). Trichomes 5-9 um wide, clearly constricted at cross walls, swollen at basal part, without a terminal hair (Figs 9B-9D). Cells distinctly shorter than wide. Heterocytes basal, sometimes in pairs, hemispherical or trapezoid, up to 10 um wide. Reproduction by trichome disintegration. Old cultures with heteropolar or isopolar filaments (Fig. 9G), straight or wavy, not tapering towards the end, 5-13 um wide, with colorless sheath, up to 4 um thick, stratified, frayed when old (Figs 9E-9F, 9J). Trichomes 5-9 um wide, width slightly varying along the length of trichome. Cells distinctly shorter than wide up to isodiametric, well developed terminal cell almost spherical (Figs 9H, 9I, 9G). Heterocytes basal and intercalary, cylindrical (Figs 9I-9J). Reproduction by isopolar hormogonia (Fig. 9K) and by trichome disintegration. Akinetes not observed.

Habitat: Brackish, estuarine.

Type locality: Newtown, Isle of Wright, England, United Kingdom. Collected by R.W. Butcher. Original collection date unspecified, likely in early 1960's.

Holotype here designated: Dry material CBFS A-081-1 is based on strain CCAP 1445/1 deposited at Herbarium of Faculty of Sciences, University of South Bohemia, České Budějovice, Czech Republic.

Reference strain: CCAP 1445/1.

Etymology: britannica (Latin), referring to the geographical area of the original sample from which strain CCAP 1445/1 was isolated.

Notes: There is no information concerning the morphology of this species in nature. It is very possible, even likely, that the morphology in culture differs from material in nature. The strain was originally identified as Microchaete grisea. It differs from Microchaete grisea by intercalary heterocytes, isodiametric cells, stratified and frayed sheath, and double and single false branching. Contrary to the original description of $M$. grisea, the trichomes in young cultures taper towards the end. In older, senescent cultures, the conical end cells and tapering disappear, and are replaced by rounded cells more similar to $M$. grisea, but the other differences between this strain and $M$. grisea provide evidence that the strain is not conspecific with this species or congeneric with Microchaete.

\section{Nunduva species LEGE 07159 (KC989702)}

Description: This strain was originally placed in Rivularia by the isolators, who sequenced the majority of the $16 \mathrm{~S}$ rRNA gene (1354 bp), but not the ITS region. It was isolated from the intertidal zone on the coast of Portugal, and so matches in ecology to other members of the genus. It is sister to Nunduva biania, although its position is poorly supported (Fig. 10). We have fairly high confidence that it belongs in the genus Nunduva, but without the ITS sequence, it is difficult to give it a specific epithet. We hope other workers will characterize this strain more fully, as it is from a coastline environmentally unique from all other origin sites for the genus, and could very well represent another new species.

Phylogenetic analysis: The Bayesian analysis based on molecular sequences obtained in this study shows two major clades of tapering forms (Fig. 10). The Calothrix cluster contains three paraphyletic strains at the base of the clade and two subclades, one with mostly brackish strains, the other with mostly freshwater and soil strains. These two clades are bisected by the Macrochaete clade (Fig. 10), suggesting that once the brackish/marine species $C$. confervicola Agardh ex Bornet et Flahault (the type species of Calothrix) is sequenced, the subclade not containing the type will require reassignment to a new or existing genus. The other major clade contains the type species of Rivularia ( $R$. atra Roth ex Bornet et Flahault), and has been consequently designated Rivulariaceae sensu stricto. Rivulariaceae sensu stricto has two major subclades, one a group of marine strains, and the second a group of brackish strains that includes the type for Rivularia. The Rivulariaceae sensu stricto has the recently described Phyllonema as a sister taxon to the whole group, and this comprises a third minor subclade in this family level cluster.

Nunduva belongs to the "marine Rivulariaceae", a well defined and delimited marine cluster that includes strains assigned to Calothrix or Rivularia, and a number of uncertain genera referred to as Marine Rivulariaceae III-V. Since the type species for Calothrix and Rivularia fall outside of this clade, all of the strains so identified will need to be assigned to other existing or new genera. This cluster of marine, tapering, heterocytous forms is sister to the one formed by Kyrtuthrix huatulcensis and "Rivularia" from the Gulf of México (Fig. 10). The strains assigned to Rivulariaceae III-V were isolated by our research group and are morphologically diverse (very different from Nunduva). All strains/populations in this cluster are found in the supratidal and intertidal waters growing tightly adhered to rocks and battered by wave action; except for Nunduva, their taxonomic identity is uncertain at this time.

Examination of sequence identity of the Rivulariaceae from this study revealed that all taxa were highly similar in their 16S rRNA gene sequence (Table 1). Nunduva species were $98.6-100.0 \%$ similar to each other; as high as $98.6 \%$ similar to some other strains lacking the morphology of Nunduva, and above $97.6 \%$ similarity to all members of Rivulariaceae sensu stricto (compare Fig. 10 with Table 1).

16S-23S ITS region (Figs 11A-12L): A comparison of the sequence data derived for the ITS region of seven clones representing four populations of Nunduva fasciculata (generitype) showed very minor differences among sequences. These differences were too minor to come to a conclusion as to whether the differences were due to possession of multiple operons or just sequencing error. The $\mathrm{p}$-distances among ITS regions of Nunduva 

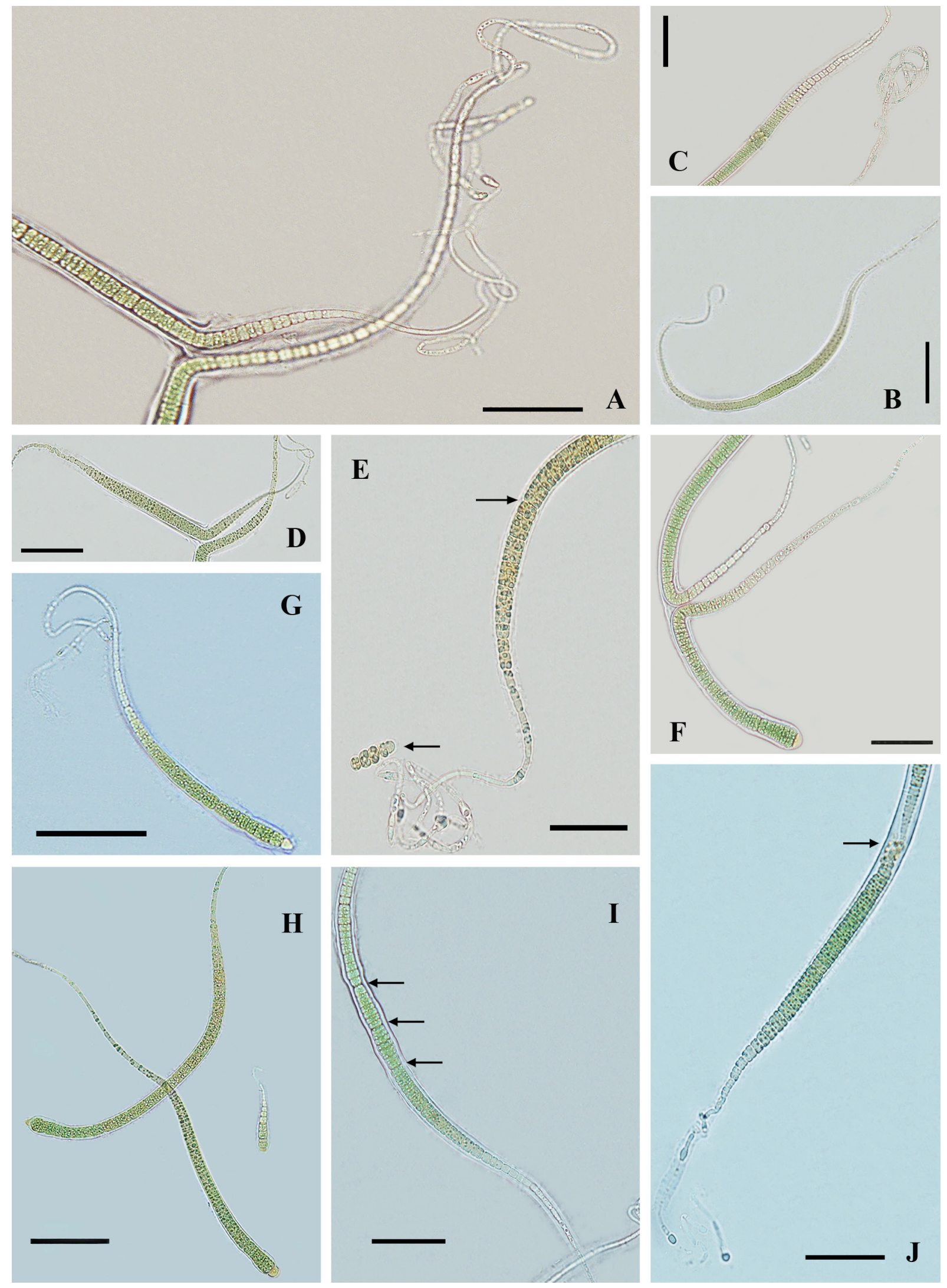

Fig. 6. Nunduva kania, culture population: (A, C-D) geminate branch and long semi-hyale hair; (B-D) isopolar filament formation; (G-H) heteropolar hormogonia develpment; (E) isopolar hormogonia (arrow), constriction (arrow), and semi-hyaline long hair; (G, E) heteropolar mature filament and basal heterocyte; (F) basal heterocyte and geminate branching; (I) isopolar hormogonia formation (arrows); (J) apical heteropolar hormogonia formation. Scale bars $20 \mu \mathrm{m}$ (A, C, E-F, I-J), $30 \mu \mathrm{m}$ (B, D, G-H). 

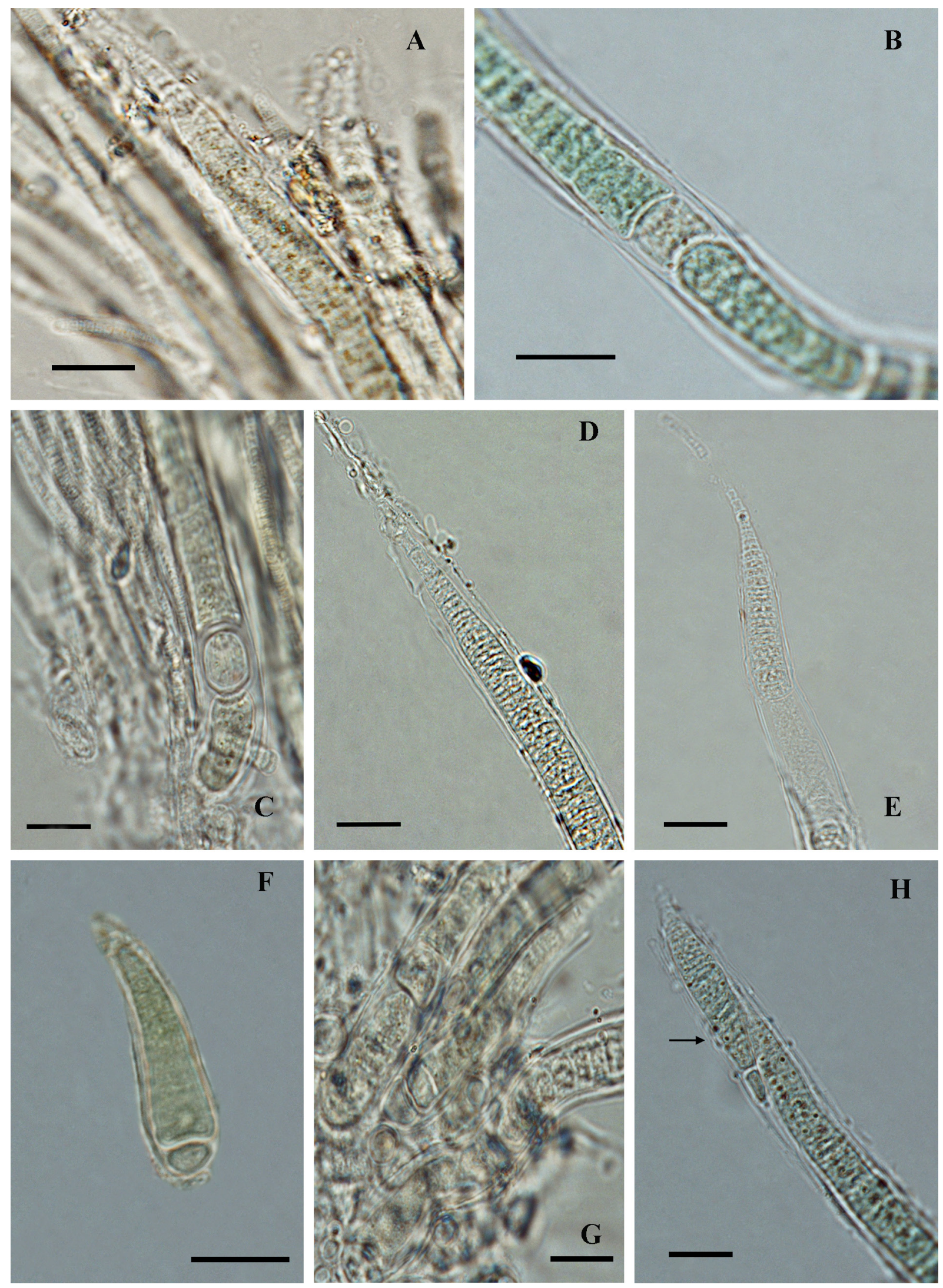

Fig. 7. Nunduva biania, environmental population: (A) filaments in fascicles; (B-C) intercalar heterocytes; (D-E) filaments tapering; (F) heteropolar hormogonia; $(\mathrm{G})$ base of filaments showing basal and intercalar heterocytes; $(\mathrm{H})$ development of isopolar hormogonia. Scale bars $10 \mu \mathrm{m}(\mathrm{A}-\mathrm{H})$. 

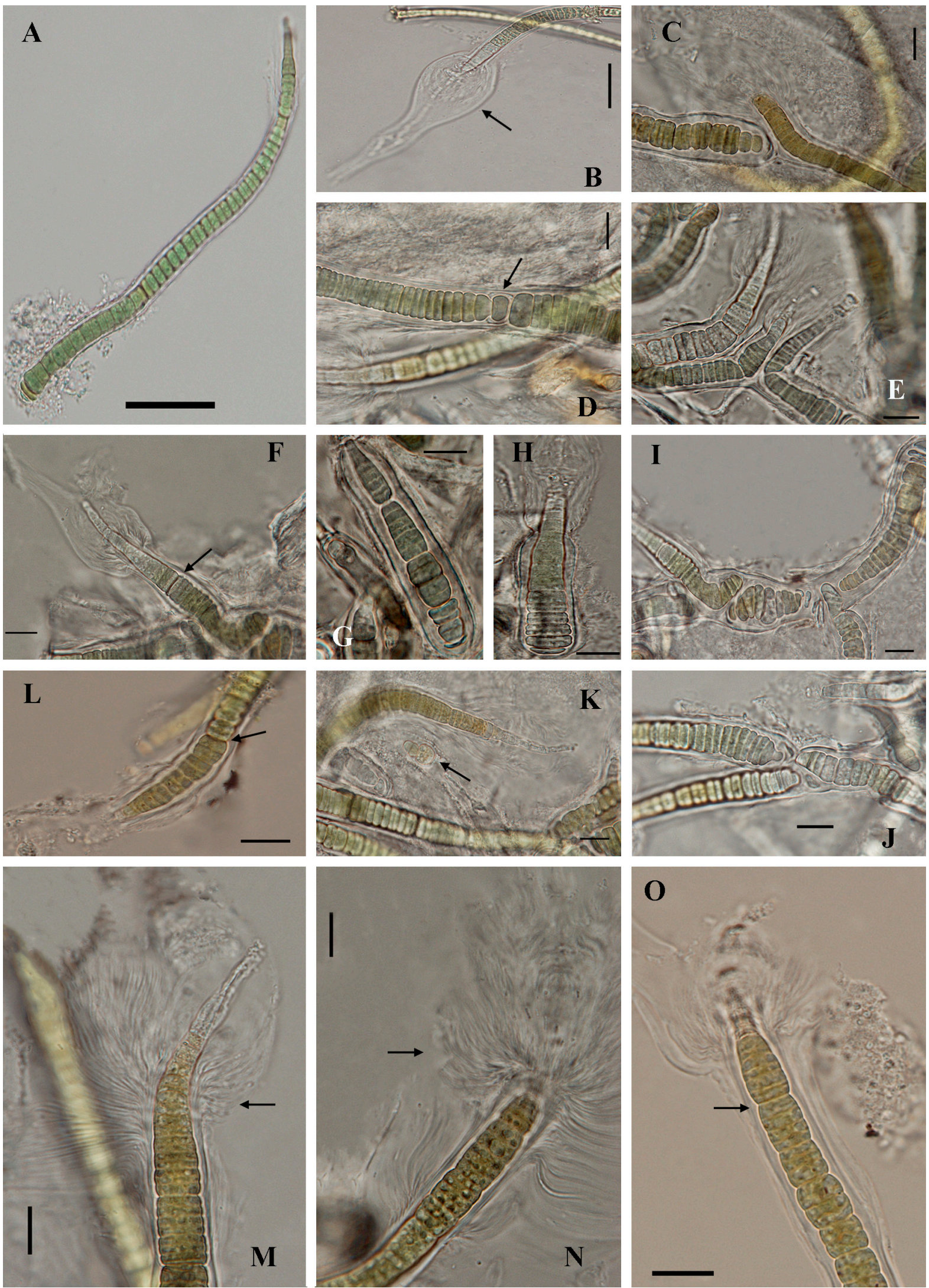

Fig. 8. Nunduva biania, culture population: (A) heteropolar mature filament; (B, M-O) lamelate, diffluent and stratified sheath; (C, E-F, I-J) single and geminate branching; (D) intercalar heterocyte; (F, L, O) heteropolar hormogonia formation by constriction (arrows); (G-H) heteropolar hormogonia; (K) heteropolar hormogonia liberation (arrow). Scale bars $20 \mu \mathrm{m}(\mathrm{A}-\mathrm{B}), 10 \mu \mathrm{m}(\mathrm{C}-\mathrm{O})$. 

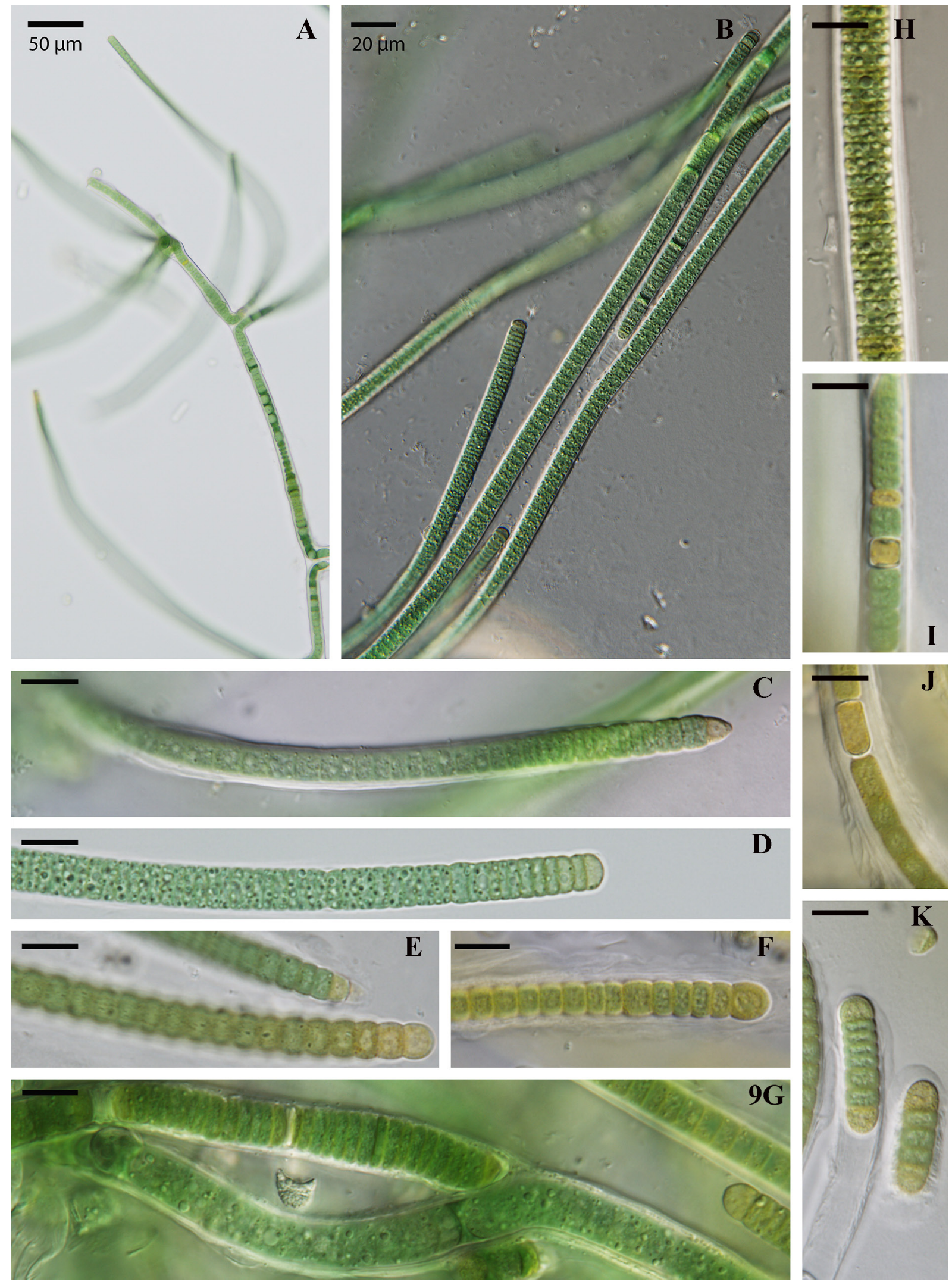

Fig. 9. Nunduva britannica, culture population, with young (A-D) and old (E-K) cultures: (A, G) single and geminate branching; (B) straight filaments; (C-F) trichomes not tapering towards ends; (J) frayed sheath; (I-J) intercalary heterocytes; (K) isopolar hormogonia. Scale bars $50 \mu \mathrm{m}(\mathrm{A}) ; 20 \mu \mathrm{m}(\mathrm{B}) ; 10 \mu \mathrm{m}(\mathrm{C}-\mathrm{K})$. 


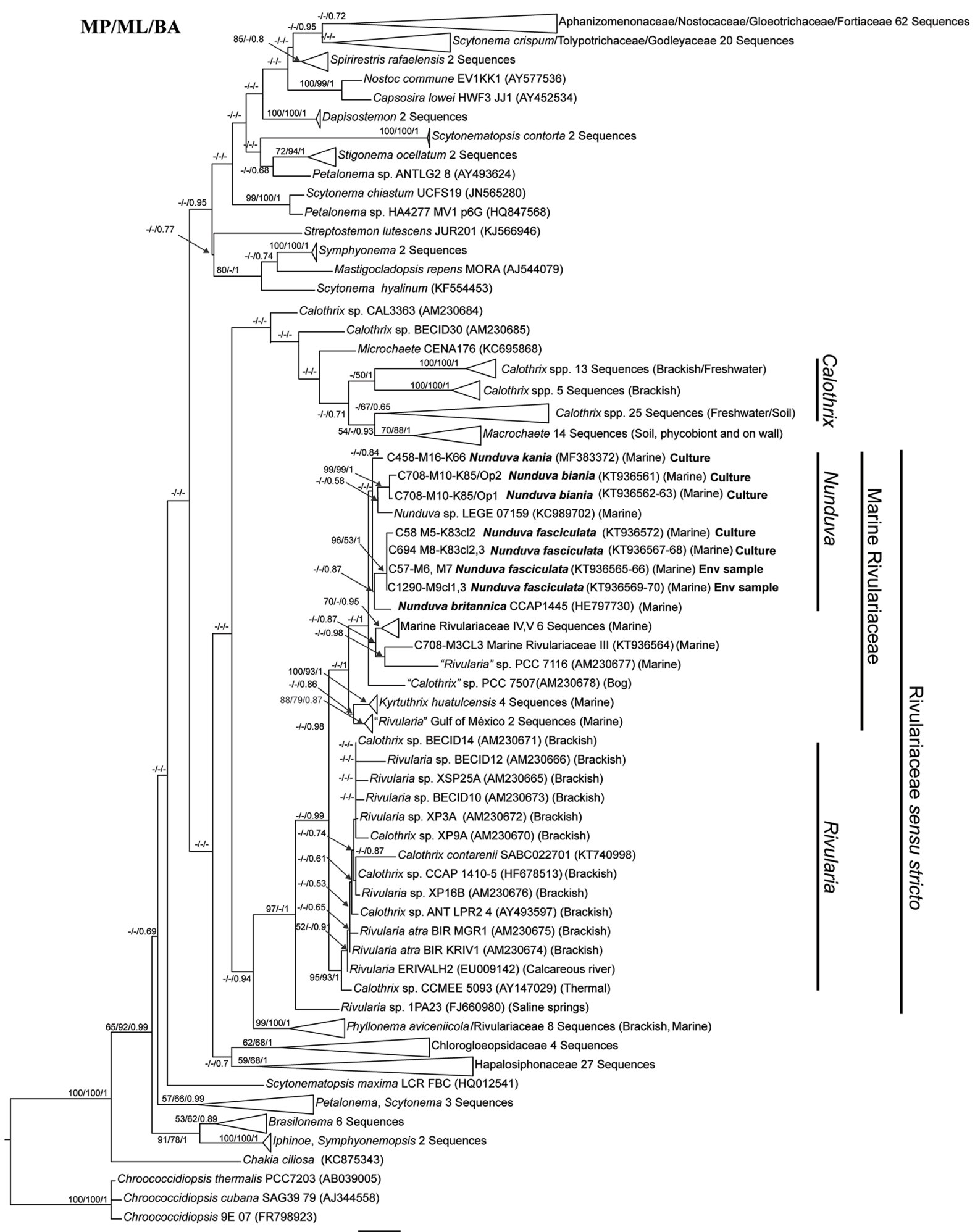

Fig. 10. Phylogenetic analysis based on 16S rRNA gene sequence data showing position of Nunduva, gen. nov. in the Rivulariaceae. The tree is based on Bayesian topology, with support values given for maximum parsimony, maximum likelihood, and Bayesian posterior probabilities analysis (MP/ML/BA). The cut-off values for bootstrap and posterior probability are 50 and 0.5 , respectively.

Fig. 12. Secondary structures of the 16S-23S ITS region, V2 helix and V3 helix in marine related sequences. V2 helix: (A) Nunduva fasciculata; (B) Nunduva kania C458; (C) Nunduva biania C708; (D) Nunduva britannica CCAP 1445/1; (E) Kyrthutrix huatulcensis; (F) "Rivularia" PCC7116. V3 helix: (G) Nunduva fasciculata; (H) Nunduva kania C458-K66; (I) Nunduva biania C708; (J) Nunduva britannica CCAP 1445/1; (K) Kyrthutrix huatulcensis; (L) "Rivularia" PCC7116. Variability in sequence between strains or between operons in a single strain is indicated by showing alternate bases within in circles. 


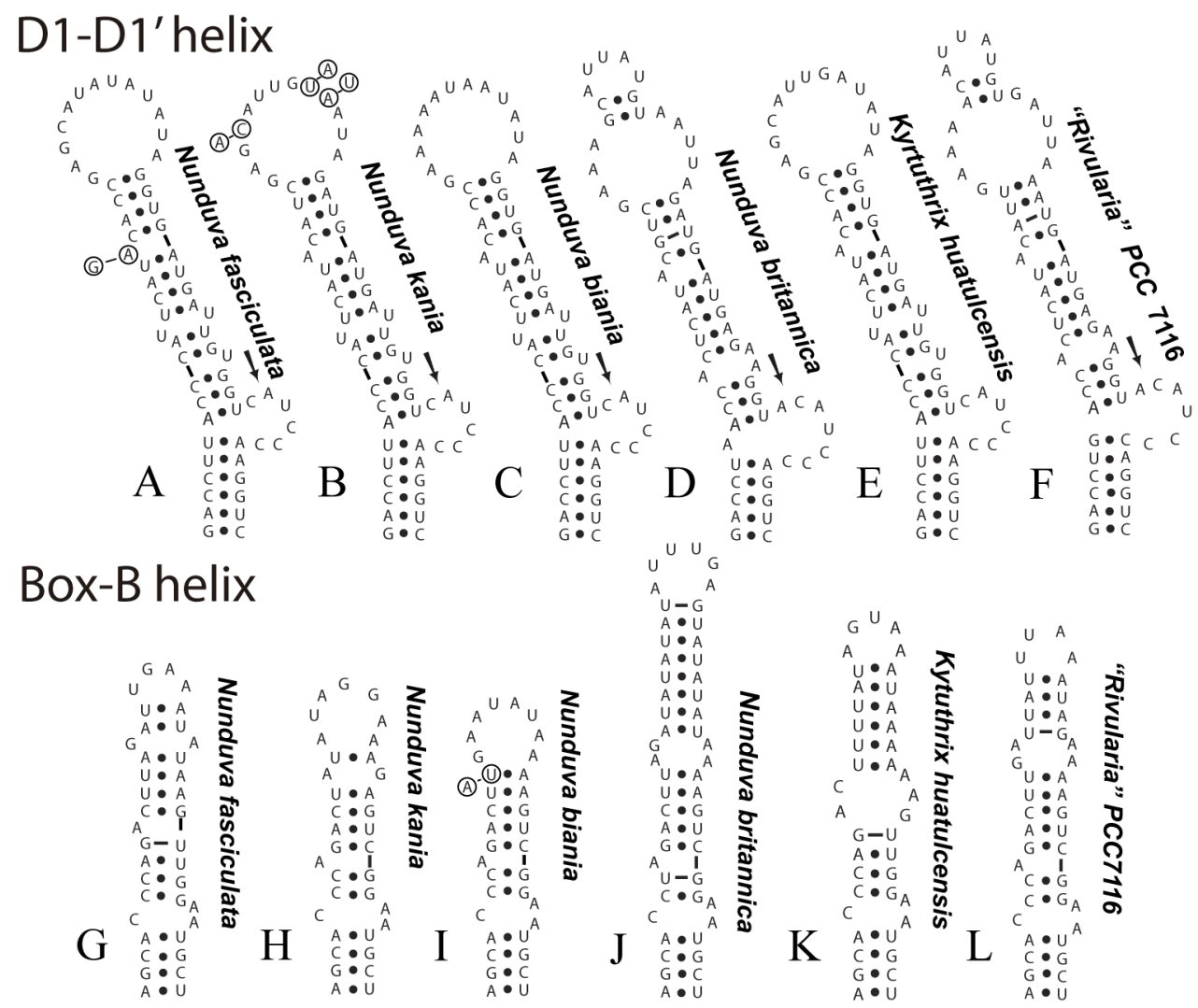

Fig. 11. Secondary structures of the 16S-23S ITS region, D-D1' helix and Box-B helix in Nunduva and related sequences. D-D1' helix: (11) Nunduva fasciculata; (11) Nunduva kania C458-K66; (11) Nunduva biania C708; (11) Nunduva britannica CCAP 1445/1; (11) Kyrthutrix huatulcensis; (11) "Rivularia" PCC7116. Box-B helix: (11) Nunduva fasciculata; (11) Nunduva kania C458; (11) Nunduva biania C708; (11) Nunduva britannica CCAP 1445/1; (11) Kyrthutrix huatulcensis; (11) "Rivularia" PCC7116. Variability in sequence between strains or between operons in a single strain is indicated by showing alternate bases within in circles.

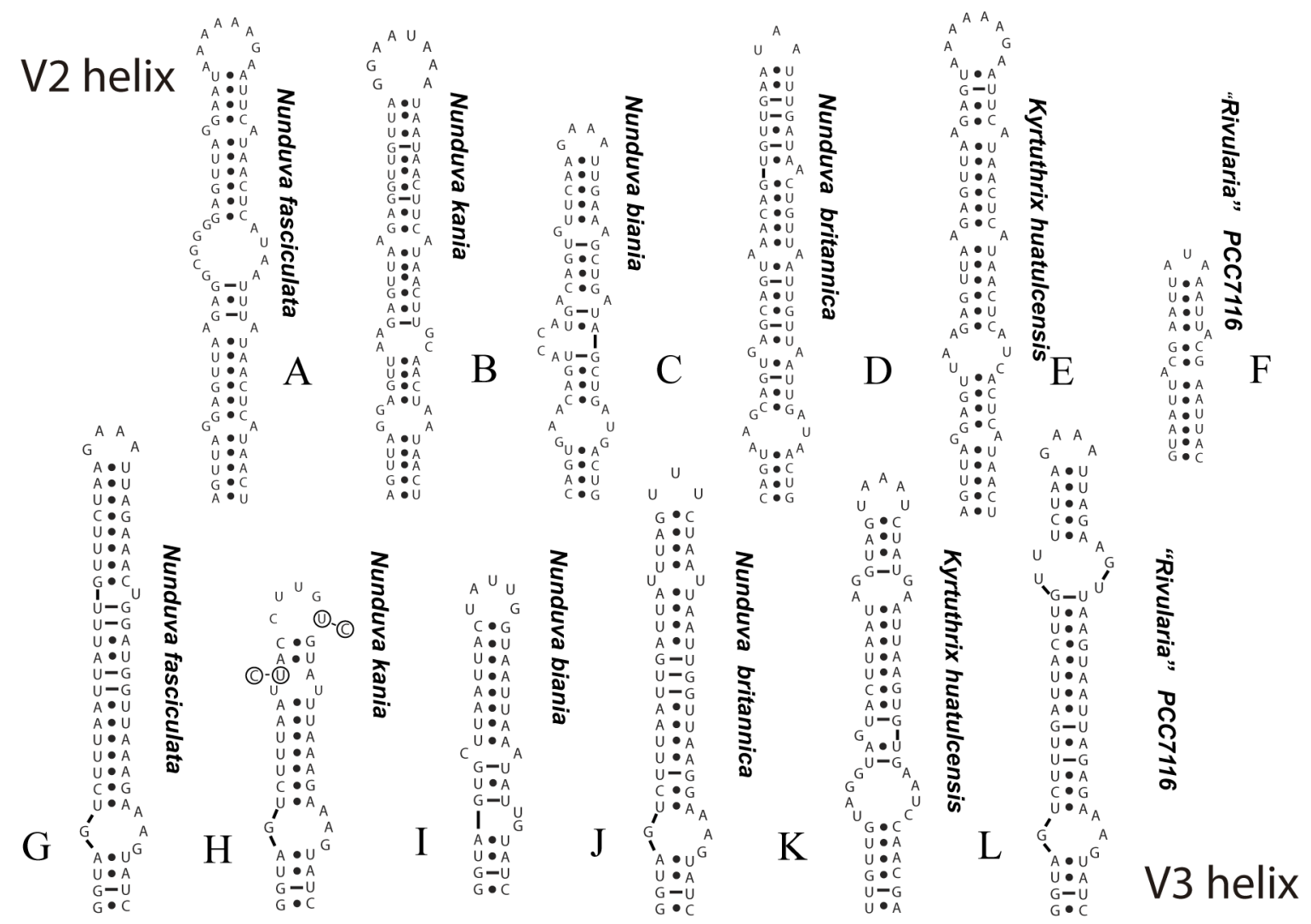


Table 1. Sequence identities between 16S rRNA gene sequences from environmental and culture populations of Nunduva spp. and closest relatives in the Rivulariaceae and two representatives from the Calothrix/Macrochaete clade.

\begin{tabular}{|c|c|c|c|c|c|c|c|c|c|c|c|c|c|c|}
\hline & & 1 & 2 & 3 & 4 & 5 & 6 & 7 & 8 & 8 & 10 & 11 & 12 & 13 \\
\hline 1 & $\begin{array}{l}\text { Nunduva fasciculata C58-M5-K83 } \\
\text { Culture }\end{array}$ & & & & & & & & & & & & & \\
\hline 2 & $\begin{array}{l}\text { Nunduva fasciculata } \mathrm{C} 57-\mathrm{M} 6, \mathrm{M} 7 \\
\text { Environmental }\end{array}$ & 99.7 & & & & & & & & & & & & \\
\hline 3 & $\begin{array}{l}\text { Nunduva fasciculata C694-M8-K148 } \\
\text { Culture }\end{array}$ & 99.7 & 100 & & & & & & & & & & & \\
\hline 4 & $\begin{array}{l}\text { Nunduva fasciculata C1290-M9 Envi- } \\
\text { ronmental }\end{array}$ & 99.7 & 100 & 100 & & & & & & & & & & \\
\hline 5 & $\begin{array}{l}\text { Nunduva britannica CCAP1445/1 } \\
\text { Culture }\end{array}$ & 98.9 & 99.2 & 99.2 & 99.2 & & & & & & & & & \\
\hline 6 & $\begin{array}{l}\text { Nunduva biania } \text { C708-M10-K85 } \\
\text { Culture }\end{array}$ & 99.0 & 99.3 & 99.3 & 99.3 & 98.6 & & & & & & & & \\
\hline 7 & Nunduva kania C458-16-K66 Culture & 98.9 & 99.2 & 99.2 & 99.2 & 98.6 & 98.9 & & & & & & & \\
\hline 8 & $\begin{array}{l}\text { Marine Rivulariaceae IV C1088-M21- } \\
\text { K118 MF383375 }\end{array}$ & 98.3 & 98.6 & 98.6 & 98.6 & 98.6 & 98.1 & 98.0 & & & & & & \\
\hline 9 & $\begin{array}{l}\text { Marine Rivulariaceae V C1230-M22- } \\
\text { K135 MF383373 }\end{array}$ & 98.9 & 99.2 & 99.2 & 99.2 & 98.6 & 98.5 & 98.4 & 99.2 & & & & & \\
\hline 10 & $\begin{array}{l}\text { Kyrtuthrix huatulcensis C708 } \\
\text { KT936560 }\end{array}$ & 98.1 & 98.4 & 98.4 & 98.4 & 98.0 & 98.3 & 98.0 & 98.0 & 98.0 & & & & \\
\hline 11 & Rivularia ERIVALH2 EU009142 & 97.6 & 97.9 & 97.9 & 97.9 & 98.0 & 97.7 & 97.4 & 97.5 & 97.5 & 98.5 & & & \\
\hline 12 & Rivularia atra BIR KRIV1 AM230674 & 97.7 & 98.0 & 98.0 & 98.0 & 98.1 & 97.8 & 97.5 & 97.4 & 97.4 & 98.4 & 99.9 & & \\
\hline 13 & $\begin{array}{l}\text { Calothrix parietina CCAP1410/11 } \\
\text { HE974991 }\end{array}$ & 92.2 & 92.5 & 92.5 & 92.5 & 91.8 & 92.1 & 92.0 & 92.7 & 93.0 & 93.4 & 93.0 & 93.0 & \\
\hline 14 & $\begin{array}{l}\text { Macrochaete psychrophila ANT SPH13 } \\
96 \text { KT336438 }\end{array}$ & 92.1 & 92.4 & 92.4 & 92.4 & 92.3 & 92.4 & 92.1 & 92.7 & 92.7 & 93.1 & 93.4 & 93.4 & 95.3 \\
\hline
\end{tabular}

Table 2. P-distances for 16S-23S ITS sequences among Nunduva fasciculata populations and close relatives. Distances $<0.03$ (bold font) are indicative of members of the same species, while distances $>0.07$ are taken as strong evidence of different species (ERWIN \& THACKER 2008; OsORIO-SANTOS et al. 2014).

\begin{tabular}{|c|c|c|c|c|c|c|c|c|c|c|c|}
\hline SPECIES/STRAIN & 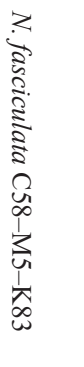 & 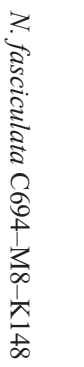 & 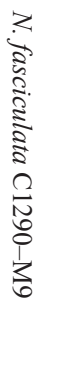 & 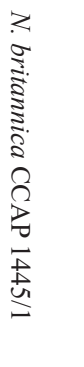 & 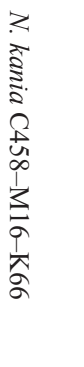 & 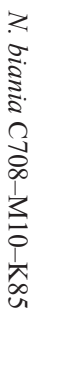 & 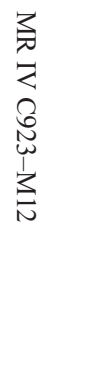 & 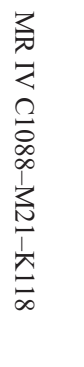 & 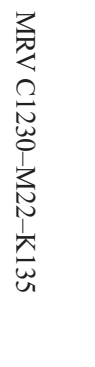 & 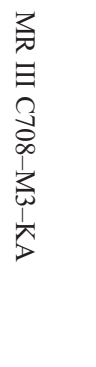 & 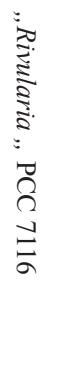 \\
\hline N. fasciculata $\mathrm{C} 57-\mathrm{M} 7$ & 0.49 & & & & & & & & & & \\
\hline N. fasciculata C58-M5-K83 & 0.33 & 0.16 & & & & & & & & & \\
\hline N. fasciculata C694-M8-K148 & 0.49 & 0.33 & 0.16 & & & & & & & & \\
\hline N. fasciculata C1290-M9 & 16.23 & 16.05 & 15.87 & 16.05 & & & & & & & \\
\hline N. britannica CCAP $1445 / 1$ & 10.90 & 10.73 & 10.55 & 10.73 & 15.72 & & & & & & \\
\hline N. kania C458-M16-K66 & 15.21 & 15.21 & 15.01 & 15.21 & 13.94 & 14.69 & & & & & \\
\hline N. biania C708-M10-K85 & 15.83 & 15.66 & 15.48 & 15.66 & 20.21 & 13.08 & 15.08 & & & & \\
\hline MR IV C923-M12 MF383374 & 15.99 & 15.82 & 15.65 & 15.82 & 19.68 & 13.78 & 15.58 & 1.62 & & & \\
\hline MR IV C1088-M21-K118 MF383375 & 16.73 & 16.56 & 16.39 & 16.56 & 18.49 & 11.40 & 15.48 & 16.50 & 17.20 & & \\
\hline MRV C1230-M22-K135 MF383373 & 18.80 & 18.61 & 18.43 & 18.61 & 14.16 & 16.16 & 11.91 & 16.20 & 16.11 & 17.55 & \\
\hline MR III C708-M3-KA KT936564 & 17.20 & 17.20 & 17.00 & 17.20 & 17.01 & 14.37 & 15.49 & 17.73 & 17.56 & 13.64 & 13.28 \\
\hline
\end{tabular}


fasciculata were all $<1.0 \%$ (Table 2 ), and consequently indicated that all belonged to the same species (ERWIN \& THACKER 2008; OSORIO-SANTOS et al. 2014). The $\mathrm{p}$-distances among ITS regions of all Nunduva species were all greater $>7 \%$, strong evidence that they belong to other species. It was possible to align the ITS regions of other related but unidentified strains with Nunduva species, but intergeneric limits have not been set based on ITS p-distance, so this is at present uninformative for taxonomy.

The secondary structure of the ITS region showed that $N$. fasciculata has identical structure in the D-D1' helix to the C458-M16-K66 N. kania and to C708-M10-K85 $N$. biania, with differences among the taxa only occurring in the sequence of the terminal loop. N. britannica had more substantial sequence differences in both the terminus and in the helix sequence between the subterminal loop and the basal unilateral bulge (Figs 11A-11F). All sequences of Nunduva show a strong similitude in their basal unilateral bulge sequence 5'-CAUCCC-3' (Figs $11 \mathrm{~A}-11 \mathrm{~F}$ see arrows), with one additional adenosine in N. britannica (5'-ACAUCCC-3' Fig. 11D).

The Box-B helices (Figs 11G-11L) were consistent in the basal clamp of the helix in all Nunduva species, but differed significantly in the terminal part of the helix and the sequence and size of the terminal loop. The sequence length of the Box-B helices also differed notably among the four species compared (Figs 11G-11J).

The Nunduva species consistently have operons with both tRNA genes, and consequently have V2 helices which often are formed between the tRNA genes (Figs 12A-12D). The V2 helices were highly divergent in primary sequence and secondary structure among the four Nunduva sequences compared, with Nunduva fasciculata having the longest sequence (Fig. 12A). The V3 helices (Figs 12G-12J) were similar in sequence in the basal clamp of the helix, but differed markedly in sequence and length for all four taxa, with Nunduva fasciculata having the longest V3 helix (Fig. 12G).

\section{Discussion}

With the onset of molecular sequencing and phylogenetics, there have recently been substantial changes in the systematics of the Rivulariaceae, including the description of new genera in the family such as Phyllonema (Alvarenga et al. 2016) and Macrochaete (BERRENDERo et al. 2016). The genera within the Rivulariaceae have been morphologically defined by their heteropolar growth, basal heterocytes and tapered trichomes. More recently, with the inclusion of the marine genus Kyrtuthrix in the family based on molecular phylogeny, the morphological definition of the Rivulariaceae had to be expanded to include genera with isopolar trichomes disposed in a heteropolar growth form (LEÓN-TEJERA et al. 2016).

The Nunduva fasciculata environmental populations were described originally as Brasilonema sp. (currently included in Scytonemataceae) by GoNZÁLEZ-RESENDIZ et al. (2015), based on morphological features such as intercalary heterocytes, development of isopolar hormogonia, occasional geminate false branches, and fasciculated filaments. Although, some morphological traits are close to the Brasilonema genus circumscription, distinctive traits such as the peculiar "bead-like" apical cell, heterocyte size and serial disposition, and distribution in supra and intertidal marine biotopes, in contrast to the freshwater and mainly subaerial habitat of typical Brasilonema species (FIORE et al. 2007; SANTA'ANNA et al. 2011; VACCARINo et al. 2012; RoDARTE et al. 2014), suggested that it belonged to a separate taxon. Even though the environmental populations have morphological traits that differ from typical Rivulariaceae, phylogenetically they clearly belong to this family and are distant from Brasilonema and other members of the Scytonemataceae. However, culture material developed more characteristic features of the Rivulariaceae, including marked trichome attenuation, pigmented terminal hairs, and frequent heteropolar hormogonia formation.

The molecular phylogenetic information obtained, supports the inclusion of Nunduva genus into the Rivulariaceae lineage. Our sequences form a well-delimited clade (Fig. 10), sister to the lineage that includes the strains assigned to Rivulariaceae sensu stricto (with type species $R$. atra, see Fig. 10). The topology of our $16 \mathrm{~S}$ rRNA phylogeny agrees with previous results with slightly different taxon sampling (BERRENDERo et al. 2016, fig. 5), where the Rivulariaceae form a well-defined cluster paraphyletic to the Calothrix group, which contains two subclades (marine and freshwater/soil).

The Nunduva 16S rRNA gene sequences had a high similarity (over 98\%) to other marine sequences (Table 1) including Kyrtuthrix huatulcensis, "Rivularia" PCC 7116, Marine Rivulariaceae IV, and Marine Rivulariaceae V. Even Rivularia sensu stricto, as represented by Rivularia atra BIR KRIV1, was $\pm 98 \%$ similar to Nunduva species. The thresholds set as clear evidence for recognition of new species or genera (STACKEBRANDT \& Goebel 1994; StacKebrandt \& Ebers 2006; Kim et al. 2014; YARZA et al. 2014), are not met in the case of Nunduva fasciculata. Indeed, all 16S rRNA sequences of members of Rivulariaceae sensu stricto are above $94.5 \%$ similar, suggesting that this very morphologically and ecologically diverse group could all belong to the same genus if only this criterion was used. However, previous studies demonstrated that Nostocales are highly similar in the 16S rRNA gene sequence (FLECHTNER et al. 2002; LUKEŠOví et al. 2009; KAŠTOVSKÝ et al. 2014) and that genera in this order frequently are more similar than $98 \%$ to at least some other genera. According to KAŠTOVSKÝ et al. (2014), to discriminate between genus and species, the similarity threshold in the $16 \mathrm{~S}$ rRNA gene can be very close $(<99 \%$ for species, and $<98 \%$ for genera). We conclude that the $16 \mathrm{~S}$ rRNA gene sequences were too similar to serve as a reliable or sole criterion for genus or species recognition in the Rivulariaceae. We agree 
with Dvořák et al. (2015) that similarity values should not be used as a primary criterion to define taxon levels in the Cyanobacteria.

The morphological differences, divergence in ITS secondary structures, and p-distances among ITS sequences among the Marine Rivulariaceae (Fig. 10) provide fairly clear evidence that this group contains multiple different species. However, the group of Marine Rivulariaceae that includes the lineages sister to the node containing Kyrtuthrix and "Rivularia" Gulf of Mexico are molecularly very similar, and it is conceivable that these undetermined taxa belong to Nunduva, despite their morphological divergence. Additional taxon sampling and sequencing of other loci could conceivably provide clarity as to whether these taxa should be members of the same genus or recognized in additional, yet-to-be described genera. The differences in 16S-23S ITS rRNA primary sequence (Table 2) and secondary structure in all marine sequences compared (Figs 11, 12), suggest to us that multiple distinct species exist in this clade.

Isopolar growth seen in Kyrtuthrix and Nunduva together with geminate false branching evident in Nunduva set these genera off from the rest of the Rivulariaceae. Tapering trichomes are typical to at least some life-cycle stages in all Rivulariaceae, but the heteropolar or isopolar nature of trichomes appears to be a less phylogenetically congruent character. Polyphasic evaluation (16S rRNA gene-based phylogeny, 16S-23S ITS secondary structure, ecology and morphology) shows clear differences between the closely related marine taxa and Nunduva environmental/culture material, providing support for this newly erected genus.

We recommend, that a complete evaluation of new taxa primarily should include if possible, the morphological description of natural and culture populations based on light and electron microscopy, the inclusion of ecological information, and molecular analysis of $16 \mathrm{~S}$ rRNA gene and other markers, such as conserved domain structure in the ITS region. Additionally, greater taxon sampling of marine Rivulariaceae is required, including the type species of Calothrix and Rivularia, as well as the analysis of a more informative multilocus data set to solve the extant polyphyly within this family as it is now conceived.

\section{ACKNOWLEDGMENTS}

The authors thank UNAM-DGAPA-PAPIIT IN223614-3 and UNAMDGAPA-PAPIIT IN225317-1 for financing this research. To Rosamond Ione Coates and Estación de Biología Tropical Los Tuxtlas, UNAM that supports to proyect "Caracterización taxonómica y ecológica de la flora béntica litoral y estuarina de la zona de los Tuxtlas". To Carolina Pineda Macedo and Jessica Jaime for image edition and Dr. Reyna Lara Martínez for excellent technical assistance with TEM images. Johansen and Hauer were supported by grant number 15-11912S from the Czech Science Foundation.

\section{REFERENCES}

Alvarenga, D.; Rigonato, J.; Branco, L.; Melo, I. \& Fiore, M. (2016): Phyllonema aviceniicola gen. nov., sp. nov. and Foliisarcina bertiogensis gen. nov., sp. nov., epiphyllic cyanobacteria associated with Avicennia schaueriana leaves. - Int. J. Syst. Evol. Microbiol. 66: 689-700.

BERRENDERO, E.; JOHANSEN, J.R.; KAŠTOVSKÝ, J.; BOHUNICKÁ, M. \& ČAPKOVÁ, K. (2016): Macrochaete gen. nov. (Nostocales, Cyanobacteria), a taxon morphologically and molecularly distinct from Calothrix. - J. Phycol. 52: 638-655.

Drummond, A.J., Ho, S.Y.W., Phillips, M.J. \& Rambaut, A. (2006): Relaxed phylogenetics and dating with confidence. - PLoS Biol 4:e88.

Dvořák, P.; PoulíčKová, A.; Hašler, P.; Belli, M.; CASAMatTA, D., \& PAPINI, A. (2015): Species concepts and speciation factors in cyanobacteria, with connection to the problems of diversity and classification. - Biodivers. Conserv. 24: 739-757.

ERwin, P.M. \& THACKer, R.W. (2008): Cryptic diversity of the symbiotic cyanobacterium Synechococcus spongiarum among sponge hosts. - Mol. Ecol. 17: 2937-2947.

Fiore, M.; SANT'ANNA, C.; AZEvedo, M.; KomáREK, J.; KAŠTOVSKÝ, J.; Sulek, J. \& Sturion, A. (2007): The Cyanobacterial Genus Brasilonema, gen. nov., a molecular and phenotypic evaluation. - J. Phycol. 43(4): 789-798.

Flechtner, V.R.; Boyer, S.L.; Johansen, J.R. \& Denoble, M.L. (2002): Spirirestis rafaelensis gen. et sp. nov. (Cyanophyceae), a new cyanobacterial genus from arid soils. - Nova Hedwigia 74:1-24.

FrÉMY, P. (1934): Cyanophycées des côtes d'Europe. - Mémoires de la Société Nationale des Sciences Naturelles et Mathématiques de Cherbourg. 41: 1-235.

Gama JR W. A.; Laughinghouse, D. \& Sant'Anna, C. (2014): How diverse are coccoid cyanobacteria? A case study of terrestrial habitats from the Atlantic Rainforest (São Paulo, Brazil). - Phytotaxa 178: 61-97.

Geitler, L (1932): Cyanophyceae. - In: Rabenhorst's Kryptogamenflora von Deutschland, Österreich und der Schweiz 14. - 1196 pp., Akad. Verlagsges., Leipzig.

Gelman, A. \& Rubin, D.B. (1992): Inference from iterative simulation using multiple sequences. - Statistical Science 7: 157-511.

Genuário, D. B.; Vaz, M. G. M. V.; Hentschke, G.; Sant'anna, C. \& Fiore, M. (2016): Halotia gen. nov. a phylogenetically and physiologically coherent cyanobacterial genus isolated from marine coastal environments. - Int. J. Syst. Evol. Microbiol. 65: 663-675.

Gold-Morgan, M.; GonZÁleZ-Resendiz, L.; LeÓN-TeJERA, H. \& Montejano, G. (2015): Description of coccoid cyanoprokaryote Nisada stipitata morphogen. et sp. nov. from the supralittoral zone in the tropical Mexican Pacific. - Phytotaxa 220: 268-276.

GonZÁleZ-Resendiz, L.; LeÓN-Tejera, H. \& Gold-Morgan, M. (2015): Morphological diversity of benthic Nostocales (Cyanoprokaryota/Cyanobacteria) from the tropical rocky shores of Huatulco region, Oaxaca, México. Phytotaxa 219: 221-232.

Gouy, M.; Guindon, S. \& Gascuel, O. (2010): SeaView Version 4: A Multiplatform Graphical User Interface for Sequence Alignment and Phylogenetic Tree Building. - Mol. Biol. Evol. 27: 221-224.

Guindon S., Dufayard J.F., LeFort V., Anisimova M., HordiJK W. \& Gascuel O. (2010): New Algorithms and Methods 
to Estimate Maximum-Likelihood Phylogenies: Assessing the Performance of PhyML 3.0. - Syst. Biol. 59: 307-21.

HALL, T. (1999): BioEdit: a user-friendly biological sequence alignment editor and analysis program for Winows 95/98/NT. - Nucleic Acids Symp. Ser. 41: 95-98.

Hauer, T.; BohunickÁ, M. \& MüHLsteinovÁ, R. (2013): Calochaete gen. nov. (Cyanobacteria, Nostocales), a new cyanobacterial type from the "páramo" zone in Costa Rica. - Phytotaxa 109: 36-44.

Hauer, T.; Bohunická, M.; Johansen, J.; Mareš, J., \& BerRendero, E. (2014): Reassessment of the cyanobacterial family Microchaetaceae and establishment of new families Tolypothrichaceae and Godleyaceae. - J. Phycol. 50: $1089-1100$.

Hentschke, G.; Johansen, J.; Pietrasiak, N.; Fiore, M.; Rigonato, J.; Sant'anna, C., \& KomáreK, J. (2016): Phylogenetic placement of Dapisostemon gen. nov. and Streptostemon, two tropical heterocytous genera (Cyanobacteria). - Phytotaxa 245: 129-143.

KAŠTovskÝ, J.; BerRendero-GomeZ, E.; HLADIL, J. \& JohanSEN, J.R. (2014): Cyanocohniella calida gen. nov. et spec. nov. (Cyanobacteria: Aphanizomenonaceae) a new cyanobacterium from the thermal springs from Karlovy Vary, Czech Republic. - Phytotaxa 181: 279-292.

Kim, M.; OH, H.S.; PARK, S.C. \& Chun, J. (2014): Towards a taxonomic coherence between average nucleotide identity and 16S rRNA gene sequence similarity for species demarcation of prokaryotes. - Int. J. Syst. Evol. Microbiol. 64: 346-351.

KomÁReK, J. (2013): Cyanoprokaryota 3. Heterocytous genera. - In: Büdel, B.; Gärtner, G.; Krienitz, L. \& Schaerl, M. (eds): Süßwasserflora von Mitteleuropa 19/3. - 1130 pp., Gustav Fischer, Stuttgart - Jena, Germany.

KomÁREK, J.; \& KomÁrKovÁ, J. (2007): Taxonomic evaluation of the cyanobacterial microflora from alkaline marshes of northern Belize. 1. Phenotypic diversity of coccoid morphotypes. - Nova Hedwigia 84: 65-111.

KomáreK, J.; KaštovskÝ, J.; Mareš, J. \& Johansen, J.R. (2014): Taxonomic classification of cyanoprokaryotes (cyanobacterial genera) Taxonomic classification of cyanoprokaryotes (cyanobacterial genera) 2014, using a polyphasic approach. - Preslia 86: 295-33.

LeÓn-Tejera, H.; Montejano, G. \& Gold-Morgan, M. (2005): Description of two interesting Scytonemaceae populations from supratidal biotopes of the mexican Pacific. -Algological Studies 117: 307-313.

LeÓn-Tejera, H.; GonZÁLeZ-Resendiz, L.; Johansen, J. R.; Segal-Kischinevzky, C.; Escobar-SÁnchez, V. \& AlBA-LoIs, L. (2016): Phylogenetic position reevaluation of Kyrtuthrix and description of a new species $K$. huatulcensis from Mexico's Pacific coast. - Phytotaxa 278: 1-18.

Lukešoví, A.; Johansen, J. R.; Martin, M. P. \& Casamatta, D. (2009): Aulosira bohemensis sp. nov.: further phylogenetic uncertainty at the base of the Nostocales (Cyanobacteria). - Phycologia 48: 118-129.

Milne, I.; Lindner, D.; BAYer, M.; HuSMeier, D.; Mcguire, G.; Marshall, D.F. \& Wright, F. (2009): TOPALi v2: a rich graphical interface for evolutionary analyses of multiple alignments on HPC clusters and multi-core desktops. - Bioinformatics 25: 126-127.

Miscoe, L.; Johansen, J.R.; Kociolek, P.; Lowe, T.; Vaccarino, M.; Pietrasiak, N. \& SHERWOOd, A. (2016): The diatom flora and cyanobacteria from caves in Kauai, Hawaii.
Taxonomy, distribution, new species. - In: CRAMER, J. (ed.): Bibliotheca Phycologica 120. - Bibliotheca Phycologica 120: 75-152.

Müller, K.; QuANDT, D.; Müller, J. \& Neinhuis, C. (2010): PhyDE® 0.983: Phylogenetic Data Editor. - Available at http:// www.phyde.de (Accessed February 2016).

Nabout, J.; Da Silva Rocha, B.; Carneiro, F. \& SAnt'anna, C. (2013): How many species of Cyanobacteria are there? Using a discovery curve to predict the species number. - Biodivers. Conserv. 22: 2907-2918.

Neilan, B. A.; Stuart, J. L.; Goodman, A. E.; Cox, P. T. \& HAwKINS, P. R. (1997): Specific amplification and restriction polymorphisms of the cyanobacterial rRNA operon spacer region. - Syst. Appl. Microbiol. 20: 612-621.

Osorio-Santos, K.; Pietrasiak, N.; Bohunická, M.; Miscoe, L.; KovaciK, L.; Martin, M.P. \& Johansen, J.R. (2014): Seven new species of Oculatella (Pseudanabaenales, Cyanobacteria): taxonomically recognizing cryptic diversification. Euro J Phycol. 49: 450-470.

Rajaniemi, P.; Hrouzek, P.; Kaštovská, K.; Willame, R.; Rantala, A.; Hoffmann, L.; KomáReK, J. \& Sivonen, K. (2005): Phylogenetic and morphological evaluation of the genera Anabaena, Aphanizomenon, Trichormus and Nostoc (Nostocales, Cyanobacteria). - Int. J. Syst. Evol. Microbiol. 55: 11-26.

REYNOLDS, E. (1963): The use of lead citrate at high $\mathrm{pH}$ as an electron-opaque stain in electron microscopy. - J. Cell Biol. 17: 208-212.

Rodarte, B.; Becerra-Absalon, I.; Montejano, G.; OsorioSANTOS, K.; Alba-Lois, L.; LeÓN-Tejera, H. \& SEGAL-KischineVZKY, C. (2014): Morphological and Molecular Characterization of Brasilonema roberti-lamii (Cyanophyceae, Nostocales, Scytonemataceae), from Central Mexico. - Phytotaxa, 164: 255-264.

Ronquist, F.; Teslenko, M.; VAn Der Mark, P.; Ayres, D.L.; Darling, A.; Hohna, S.; Larget, B.; Liu, L.; Suchard, M.A. \& HuELSENBECK, J.P. (2012): MrBayes 3.2: Efficient Bayesian Phylogenetic Inference and Model Choice Across a Large Model Space. Syst. Biol. 61: 539-42.

SANT'ANNA, C.L. (1997): Cyanophyceae marinhas bentónicas da regiao de Ubatuba, Sp, Brasil. -Hoehnea 24: 57-74.

Sant'anna, C.L.; Corderio-Marino M.; Braga M. do R. DE A. \& Guimaraes S.M.P. DE B. (1985): Cyanofíceas marinhas benthónicas das Praias de Peruíbe dos Sonhos, município de Itanhaém, SP, Brasil, 1. - Rickia 12: $89-112$

SANT'ANNA, C. (1988): Scytonemataceae (Cyanophyceae) from the state of Sao Paulo, Southern Brazil. -Nova Hedwigia, 46: 519-539.

SANT'ANNA, C.; AZEvedo, T.; FioRe, M.; LORENZI, A.; KAŠTOVSKÝ, J. \& KomÁrek, J. (2011): Subgeneric diversity of Brasilonema (Cyanobacteria, Scytonemataceae). Revista Brasileira de Botânica 34: 51-62.

StACKebrandT, E. \& EBERs, J. (2006): Taxonomic parameters revisited: tarnished gold standards. - Microbiology Today 33: 152-155.

Stackebrandt, E. \& Goebel, B.M. (1994): Taxonomic note: a place for DNA-DNA reassociation and 16S rRNA sequence analysis in the present species definition in bacteriology. - Int. J. Syst. Bacteriol. 44: 846-849.

Tamura, K.; Stecher, G.; Peterson, D.; Filipski, A. \& Kumar, S. (2013): MEGA6: Molecular Evolutionary Genetics Analysis Version 6.0. - Mol. Biol. Evol. 30: 2725-2729.

Thompson, J.D.; Higgins, D.G \& GiBson, T.J. (1994): CLUSTAL $\mathrm{W}$ : improving the sensitivity of progressive multiple 
sequence alignment through sequence weighting, position-specific gap penalties and weight matrix choice. - Nucleic. Acids. Res. 22: 4673-4680.

VACCARINo, M. \& Johansen, J. (2012): Brasilonema Angustatum sp. nov. (Nostocales), a New Filamentous Cyanobacterial Species From the Hawaiian Islands. - J. Phycol. 48: 1178-1186.

WaterburY, J.B.; VAlois, F.W. \& Franks, D.G. (1986): Biological and ecological characterization of the marine unicellular cyanobacterium Synechococcus. - In PLATT, T. \& LI, W.K.W. (eds): Photosynthetic Picoplankton.Canadian Bulletin of Fisheries and Aquatic Sciences, 214: 71-120.

Wilmotte, A.; Van Der Auwera, G. \& De Wachter, R. (1993): Structure of the 16S ribosomal RNA of the thermophilic cyanobacterium Chlorogloeopsis HTF
('Mastigocladus laminosus HTF') strain PCC7518, and phylogenetic analysis. - FEBS Letters. 317: 96-100. ZuKer, M. (2003): Mfold web server for nucleic acid folding and hybridization prediction. - Nucleic. Acids. Res. 31: 3406-3415.

Yarza, P.; Yilmaz, P.; Pruesse, E.; Glöckner, F.O.; Ludwig, W.; SChleifer, K.; WhitMan, W.B.; EuzÉBy, J.; Amann, R. \& Rosselló-Móra, R. (2014): Uniting the classification of cultured and uncultured bacteria and archaea using 16S rRNA gene sequences. - Nature Rev. Microbiol. 12: 635-645.

(C) Czech Phycological Society (2018)

Received February 28, 2017

Accepted August 24, 2017 